\title{
SEISMIC ANALYSIS \\ LIVERMORE POOL TYPE REACTOR FACILITY, LAWRENCE LIVERMORE LABORATORY
}

\author{
R. C. Murray \\ F. J. Tokarz
}

November 15, 1973

Prepared for IJ.S. Atomic Energy Commission under contract No. W- 7405-Eng- 48
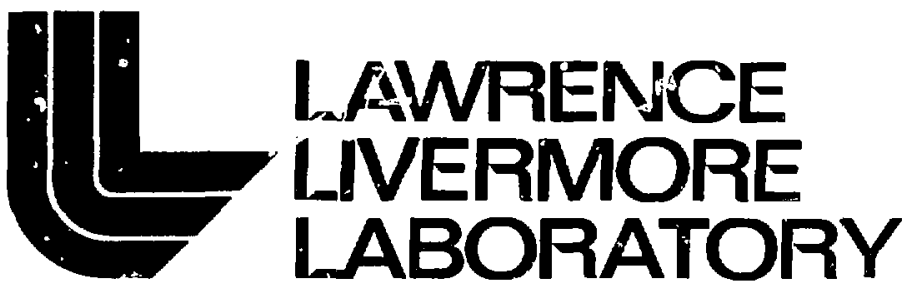

University of California/Livermore 
ROTICl:

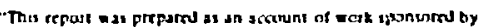
the Unites Sistes Cionrinment Sirithe the Urutes Ststes not

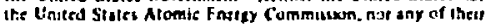

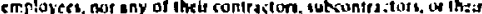

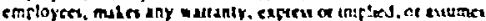

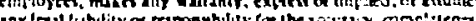

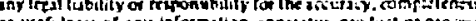

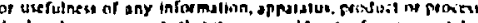

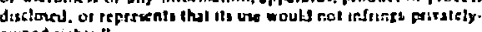
owred richie."

Printed in the United States of America Available from

National Technical Information Service

U.S. Department of Cornmerce 5285 Port Royal Road

Springfield, Virginia 22151

Price: Printed Copy \$ : Microfiche $\$ 0.95$

$\frac{1}{\text { Pages }}$
$1-50$
$51-150$
$151-325$
$326-500$
$501-1000$

NTIS

Selling Price

$\$ 4.00$

$\$ 5.45$

$\$ 7.60$

$\$ 10.60$

$\$ 13.60$ 
$[11)-4500,1(-.38$

fingineer ny and liquipment

\section{㢟 \\ LAWAENCE LNERMOAE LABOAATOAY \\ unversityor Cattoma unmore Cevioma 94550}

[CR1.-51

\section{SEISMIC ANALYSIS \\ LIVERMORI: POOL TYPE REACTOR FACILITY, LAWRENCE LIVERMORE LABORATORY}

R. C. Murity

r. I. Tuk.1\%:

MS. Iate: beramber li, 1:1;

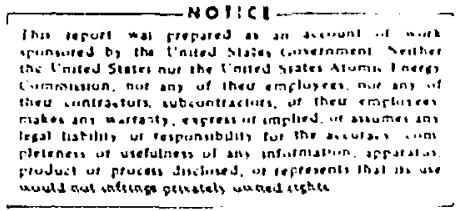




\section{Contents}

\begin{tabular}{|c|c|c|c|c|c|c|c|c|c|c|c|c|}
\hline Abstrect & . & • & $\cdot$ & ' & $\cdot$ & 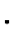 & $\cdot$ & • & - & & & ' \\
\hline introduction & . & . & . & • & • & • & • & . & $\cdot$ & $\cdot$ & . & \\
\hline Description of I prr & . & . & • & $\cdot$ & . & $\cdot$ & . & • & $\cdot$ & • & & \\
\hline Containment Building & - & - & · & · & - & - & . & & ' & • & - & \\
\hline Reactor Shicld & . & • & · & $\cdot$ & . & ' & . & & . & • & . & • \\
\hline Overhead Bridge Crane & : & . & . & . & - & - & • & & e & & - & • \\
\hline Reactor Shicld Top Sitru & ueture & - & . & $\cdot$ & • & - & - & $\cdot$ & . & $\cdot$ & • & • \\
\hline Heal Exchanger & . & $\cdot$ & . & $\cdot$ & ${ }^{\circ}$ & & . & & & & . & - \\
\hline Sare Shutdown airthquake & · & . & . & . & $\cdot$ & . & • & 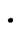 & 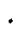 & & $\cdot$ & \\
\hline I.iquefaction Potential & . & . & . & . & . & . & $\cdot$ & . & . & $\cdot$ & . & . \\
\hline Scil-sitruzture Interaction & bifect & . & . & • & $\cdot$ & ${ }^{\circ}$ & , & ${ }^{\circ}$ & - & . & • & . \\
\hline Reactor Shicld Analysis an & ind Hes & & . & - & $\cdot$ & $\cdot$ & $\cdot$ & • & $\cdot$ & ${ }^{\circ}$ & • & - \\
\hline Containment Sulding Anal & ysis a & & Hlts & & . & , & " & $\cdot$ & ${ }^{\circ}$ & ${ }^{\circ}$ & • & - \\
\hline Oher Calegory I Siructura & A Anal & & ad & ist & & & ' & $\cdot$ & & & $\cdot$ & . \\
\hline Overhead Bridge Crane & Suppro & & clu & & . & • & . & • & " & & • & - \\
\hline Reactor shicld Top ste & acture & . & $\cdot$ & . & - & • & . & • & . & $\cdot$ & • & . \\
\hline Heat Exchanger Support & i sitrus & & . & $\cdot$ & - & - & $\cdot$ & • & $\cdot$ & . & - & • \\
\hline Conclusions . & . & • &. & . & * & . & . & . & • & . & • & . \\
\hline Acknouledgments & . & . & . & . & · & - & a & $\cdot$ & • & & . & • \\
\hline References. & . & . & . & $\cdot$ & $\cdot$ & & - & $\cdot$ & - & & & • \\
\hline Bibliography & . & & . & - & - & & . & • & & & & • \\
\hline
\end{tabular}




\title{
SEISMIC ANALYSIS \\ LIVERMORE POOL TYPE REACTOR FACILITY, LAWRENCE LIVERMORE LABORATORY
}

\begin{abstract}
A seismic evaluation of the l.ivermore Pool Type Reactor Facility located al the Lawrence Livermore Liboratory was conducted as part of a safely analysis being prepared for the Atonic Energy Commisaion. The safe shutjown earthquake for the lawrence l.ivermore Laooratory site is defined, along with a brief discussion of its basis. The method

of analysis and results are summarized for all critical cumponents.

We conclude that the biological shield and containment building should withstand the safe shutdown earthquake without failures. The crane and heat exchanger could fail under worst-case loading conditions. Recorimendations for modifying the crane and heat exchanger support are presented.
\end{abstract}

\section{Introduction}

Safety Analysis Reports (SAR) are required by the U.S. Atomic Energy Commission as part of applications for construction permits and operating licenses for all nuclear power piants. The principal purpose of these reports is to inform the Commission of the nature of the facility and plans for its use. The Commission requires that the information provided be of sufficient detail to determine if the facility can be built and operated safely. The SAR is the principal document whereby the applicant provides this information.

Although the Livermore Pool Type Reactor (LPTR) is a nuclear reactor used for research, not a nuclear power reactor, the Commission has requested that the
Lawrence Livermore l.aboratory prepare and submit an SAR. Such a report is in preparation. One aspect of this effort involves an seismic investigation of the 1.PTR facility. This report summarizes the seismic investigation.

In February 1972, the Regulatory Staff of the Commission issued a standard format for SARs. This document identilies the principal detailed information that is required by the stafi for its evaluation. (Previously the Commission specified the required information in general terms.) The standard format requires that each facility meet the seismic criteria defined in Appendix $A$ of $10 \mathrm{CFR}$ Part 100 entitled "Seismic and Geologic Siting Criterie for Nuclear Power Plants." 
This Appendix describes the investigations required to obtain the gcologic and seiamic data necessary to determine site sultability and provide reasonable assurance that the facility can be constructed and operated at the site without undue risk to the health and safety of the public. Procedures are described for determining the quantitative vibratory ground motion levels for design basis and to what extent the facility need be designed for surface fauiting.

When investigating possible vibratory efferts, $A$ ppendix $\Lambda$ requires that two levels of earthquake motions be considered, a Safe Shutdown Eas thquake (SSE) and an Operating Basis Farthquake (OBE). The SSE is defined as the largest possible earthquake at the site. It produces the maximum vibratory ground motion that the structures, systems, and components needed for safe operation must survive, intact and functional. These structurea, systems, and components are those necessary to ensure: (1) the integrity of the reactor coolant pressure boundary, (2) the capability to shut down the reactor and maintain it in a safe shut-down condition, or (3) the capibility to prevent or mitigate the consequences of accidents which could result in potential off-site exposures. The OBE is defined as the largest probable earthquake at the site. It produces the vibratory motion that structures, systems and components needed for power generation must survive intact and operational.

This report considers the possible effects of vibratory ground motion produced by a SSE on the LPTR faciity. The SSE used is based on the information in Refs. 2 and 3. The discussion in these references of possuble surface faulting at the $i$ awrence livernure laborator: site will not be repeateribe. The i prek facility was not investigated for a ,osstble OBE.

All structural analyit s employed the response spectra approach, using the na: :ral pe iods, mode thapes and damping ratios of the structure. This approact vields conservative response estimates. Damping values equal to $2 \%$ of critical viscous damping were ueed for all analysis. The same damping values were used for all materials and modes of vibration. rr. $2 \%$ value provides a conservative estimate of the actual darnping in the structures when stresses ...proach the yicld point. In the dynatric analysis the root mean square procedure was used for combining the modal reymanse of the reactor shield and contarrinent builangr as shown below:

$$
v_{\text {max }}=\sqrt{r_{1}^{2}+v_{2}^{2}+\cdots v_{n}^{2}}
$$

where: $v_{1}, v_{2}, \cdots v_{n}=\operatorname{modal}$ response quantities (i.e., displacemerits, accelerations, stresses) $V_{\max }=$ maximum value of quantity.

Yield and ultumate stresses of the construction materials were used for comparison with calculated stresses. Displacement sriteria were based on physical interference between adjacent components.

The contents of this report include:

- A brief description of the LPTR facility

- A definition and discussion of the basis for the SSE 
- A discussion of the possibility of liquefactuon and the effects of soilstructure interaction

- A brict discussion of the method of analysis and results for the reactar shield, the containment butding. the owerhead bridge crane, the reactor top structure. and the heat exchanger support structure.

- Conclusions rege-ting the structural integrity of the 1. PTh facility when cyposed to ground motions defined by the set:.

\section{Description of LPTP}

The ILPJT is a tank-type therme: research reactor. The light-water moderated a'd cooled scactor core generates a peak flux approaching $10^{14} \mathrm{n} / \mathrm{cm}^{2}$ - sec at llwe present operating power of $3 \mathrm{MW}$. Fusl used in the reacto: is enriched with 235 .

The reactor facility is a versatile and flexible tool for the various research programs at the Laboratory. Six horizontal beam tubes, two thermal columns and two pneumatic tubes plus a number of irradiation ports and in-core facillties provide access to the llux. Fi gure 1 shows a section through the reactor.

Th, LPTR was designed, constructed and tested by the Foster. Wheeler Corporation. Construction began in October 1956 and was campleted April 1958. From 1358 to 1960 the reacior was operated at I MW, Modification of the containinent building equipment to allow increased operating power began in 1960. In January 1967 the maximum power level was increased to $3 \mathrm{MW}$. Reference 4 presen.s tr = final design details and modificitiuns up to 1967 , a description of the reactor, related mechanical and electric control systems and a disclissicn of operating procedures and associated hazards.
Figure 2 shows a cr.ss-ection :ll-cugh the renctor bullding identifying those structures considered in the salysis. These inelude the contanmerit buildune, the reactor shield, reartor top structure, the britge crane and the heat oxchanger. $\wedge$ briet tescription of each follows:

\section{CONTAINMEN"T BLIIITING}

The reactor is foused in a controlledleakage steed building alesigned to contain radionctive efflurits under all conditions. The bullding is $80 \mathrm{dt}$ in diameter and $52 \mathrm{ft}$ high. The bullding is a cyltidrical shell of welded steel plates $1 / 1$ in. thick reinforced with stiffencr rings and has a domad gelfsupporting roof of $5 / 16$ in. steel plates. Large bars buried in a nuasive reinfucced concrete ring wall anchor the base of the structure.

The containment building was de3igned and tested for an internal pressure of $2 \mathrm{psi}$. In addition, the disign considered a $12 \mathrm{lb} / \mathrm{ft}^{2}$ wind loading and lateral earthquake loading per the 1952 Uniform Building Code with a seismic coefficient of 0.2 (i.e., base shear equals 0.2 times the tot.t seismic weight). 


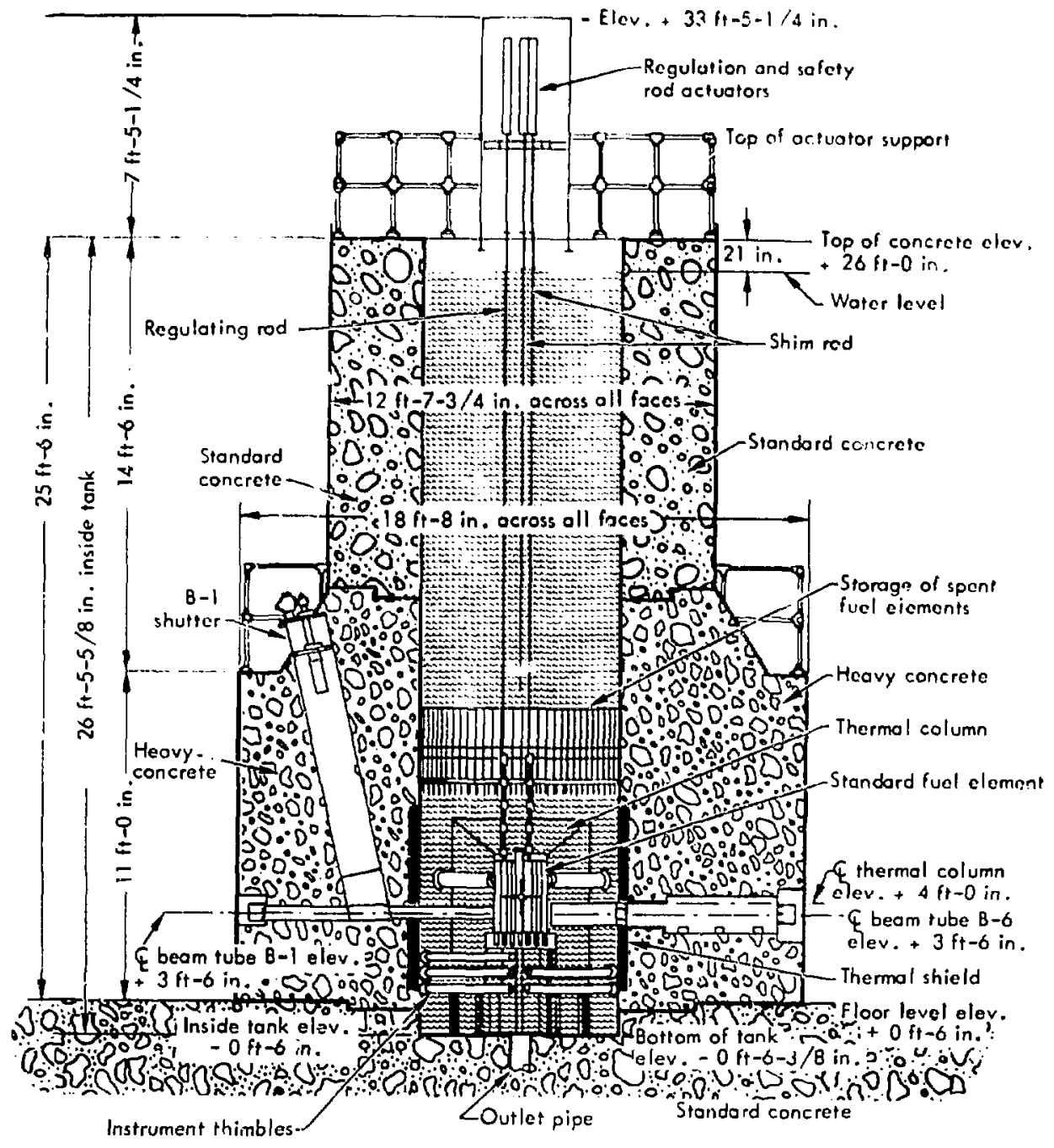

Fig. 1. Livermore pool type reactor, N-S stctional view.

\section{REACTOR SHIELD}

The reactor shield consists of an aluminum tank $3 / 8 \mathrm{in}$, thick, 79 in. dianeter, and $26.5 \mathrm{ft}$ deep surrounded by a concrete biological shield as shown in Fig. 1. Magnetite concrete with a unit weight of $225 \mathrm{bb} / \mathrm{ft}^{3}$ surrounds the fuel elements while standard concrete fills the upper shield section. The top of the ieactor is enclosed by a 1/4-in. thick removable working platform. The plates 


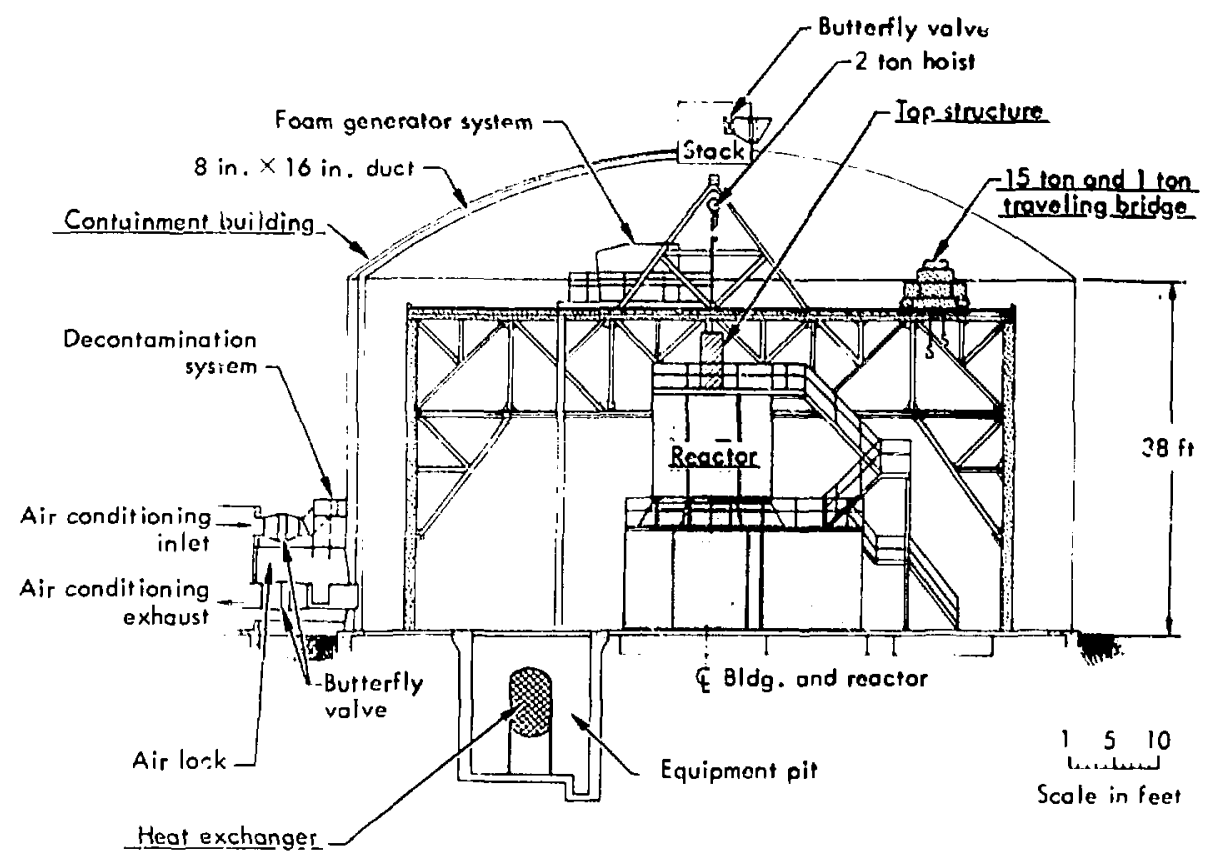

Fig. 2. LP'TR reactor bullding, E-W section facing north.

rest on cantilevered wide-flange beams which support the control rod actuator housing (top siructure).

The shield was also designed to comply with the 1952 Uniform Building Code, using a seismic coefficient of $\mathrm{C} .133$ and a wind loading of $20 \mathrm{lb} / \mathrm{ft}^{2}$ normal to vertical surfaces.

\section{OVERHEAD BRIDGE CRANE}

A 15-ton traveling bridge crane services the main area of the reactor facility. The crane has a maximum hook height of $37 \mathrm{ft}$ clearing the highest pooltop structure by about $4 \mathrm{ft}$. The crane trolley and hoist have variable-speed $\mathrm{s}$ otors, with a low-speed range and magretic brakes.
The crane support structure is a welded and bolted structural steel irame.

Design loads for the crane structure were deadload, increased $25 \%$ for vertlcal impact due to crane operations, and lateral loads from either crane accelerations or irom seismic consideratic rs (UBC. Zane? seismic coefficient $=0.2)$.

\section{REACTOR TOP STRUCTIIRE}

The reactor top structure houses the control rod actuators and also covers the top of the reactor pool. The structure is cantilevered from the concrete reactor shield. The top structure was designed according to the 1952 Uniform Building Code. Seismic loads were not congidered. 
HEAT EXCHANGER

The heat exchanger is part of the reactor primary coolant systam and is located in the equipment pit. The heat exchanger is supported by a rigid frame fabricated from angles and channels.

\section{Safe Shutdown Earthquake}

The safe shutdown earthquake (SSE) is defined as the largest possible earthquake for the site. This is the earthquake that safety related reactor components must tolerate and still remain functional. Determination of the SSE and its local ground motion requires investigations into the site geology, seism.icity, and tectonics. The SSE used for this investigation is based on a postulated $5.7 \mathrm{magni-}$ tude earthquake located on the Tesla fault at a 2.5 mile epicentral distance to

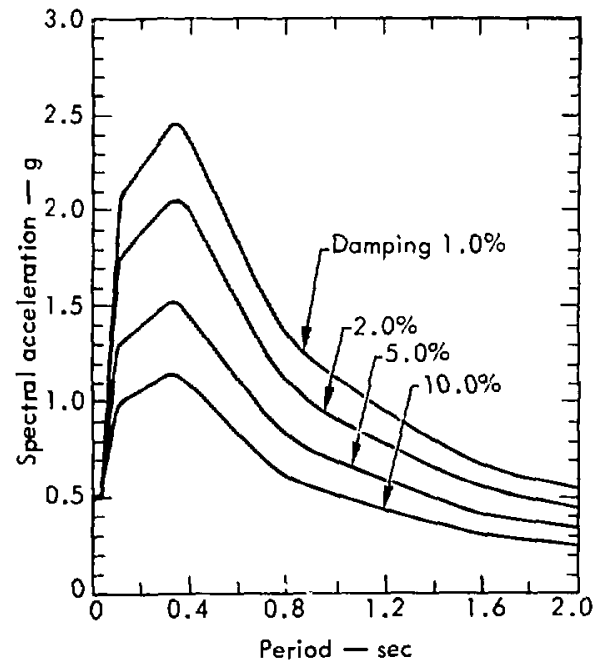

Fig. 3. Safe shutdown earthquake (SSE) spectra. For vertical component multiply acceleration scale by $2 / 3$. For operating basis earth. quake (OBE) multiply acceltration scale by $1 / 2$. the laboratory. The Sist gives an estimated peak horizonial acceleration of $0.5 \mathrm{~g}$ and 3 vertical acceleration of $0.33 \mathrm{~g}$ at ground level. The frequency content of the SSE is defined by the response spectra shown in lig. 3 . The SSE used is taken from Ref. 2, a project to develop seismic criteria for $"$ new plutonium facility located 1400 it from the LPTR sitr. The investigation included gravity, magnetic, geode.ic, hydrologic, and selsmic refraction surveys.

Reference ? concerns itsclf primarily with an investigation of faulting in the vicinity of the laboratory. An earlier investigation ${ }^{3}$ developed sessmic design criteria without particular reference to the reactor siting crtteria of the $A \mathrm{C}$. The seismic criteria presented in Ref, 3 were basud on postulited large earthyuakes located on more distant fit uls to the west of the Labo atory. These faults and their relation to the 1.1.1. site are shown in Fig. 4, with maximum pustulated earthquakes listed in Table 1 .

Table 1. Maximum postuelted distant earthquakes, Ref. 3.

\begin{tabular}{lcc}
\hline Fault & Magnilude & $\begin{array}{c}\text { Epicentral } \\
\text { distance } \\
\text { (mi) }\end{array}$ \\
\hline San Andreas & 8.3 & 35 \\
Hayward & 7.5 & 17 \\
Calavaras & 7.0 & 10 \\
\hline
\end{tabular}




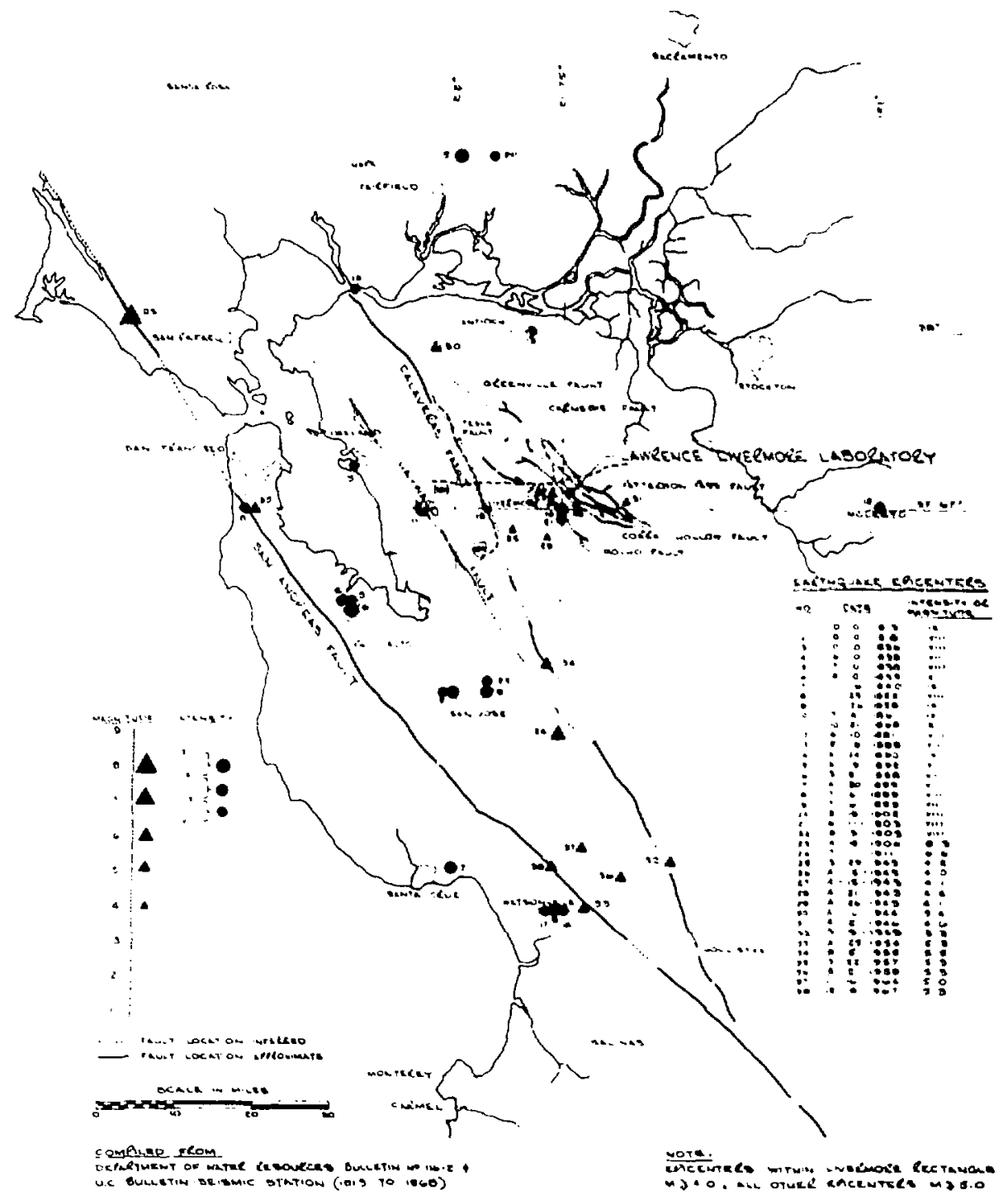

Fig. 4. Important faults and earthquake epicenters located within $60 \mathrm{mi}$ of 1.PTR.

The estimated neak ground acceleration from any of these earthquakes was $0.4 \mathrm{~B}$ at the Laboratory site.
Another report ${ }^{5}$ recommends a higher level of horizontal ground acceleration of $0.8 \mathrm{~g}$ and slightly different design 
spectra. However, after a carclul

review of both works the Laboratory has decided to use the 0.5 ig SSE as recommended in Ref. 2 for the evaluation and design of the laboratory's critical tacilitics."

\section{Liquefaction Potential}

The development of the SSE criteria assunce the subsurface soll conditions at the Laboratory site to be stable. This section presents arguments to justify this assumption.

Licuefaction describes the condition of soll instabllity that can occur in saturated cohesionless materials subjerted to vibrations. During vibration the soil tends to compact, increasing the pore-water pressure. The increased water pressure cauzes an upward flow that liquifies the sand above. This can make structures founded on the slte settle or silt.
Liquefaction occurs in tine sanda located below the ground water table. The sands must be loose and able to compact. Relative densly (I) $r$ ) is a measure of the sand's state of compaction. A sand with a $D_{r}$ of $100 \%$ is at its densest. Also, in order to liquily, there must be a path through the sand for the upwar Nlow of water. Without low $D_{r}$ and a path for water llow, no potentlal liquefaction problem exists.

The subsurface soll conditions at the 1.LL. site are summarized in Fig. 5 (Ref. 7). The only saturated material is the Livermore formation. Since this
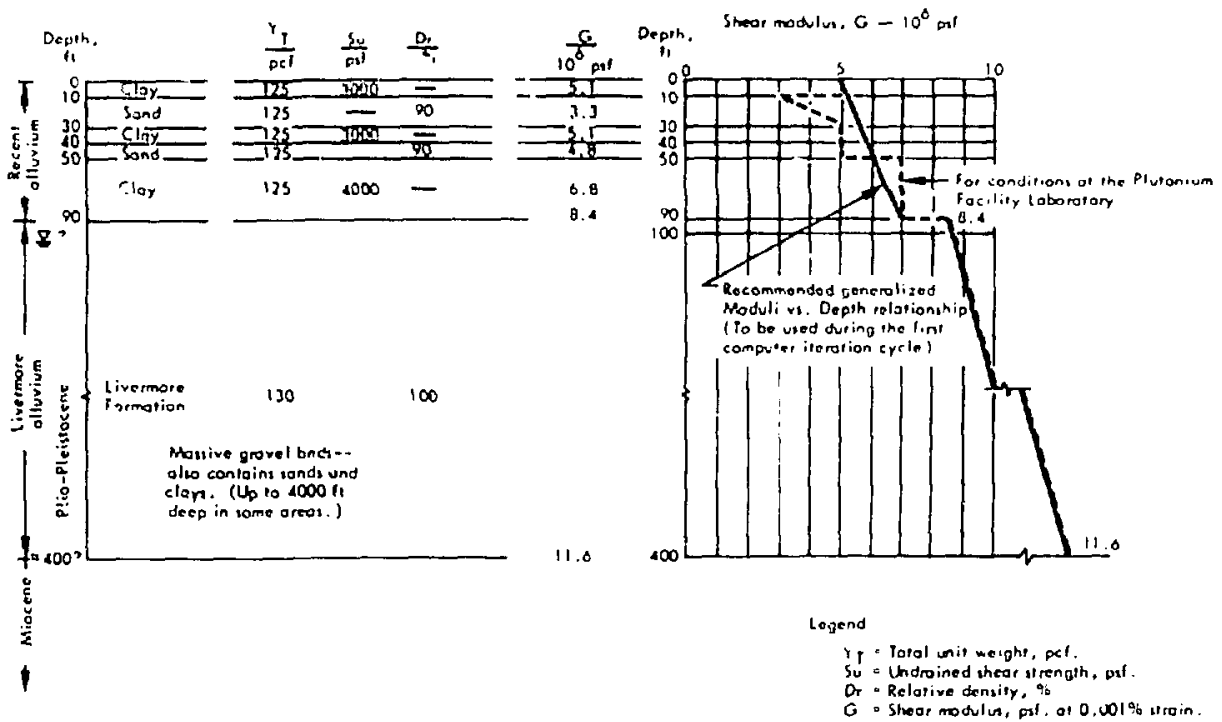

Fig. 5. Generalized soil properties at Livermore stte. 
material is coarse and has a rolative density of $100{ }^{\circ}$, it will not compact under vbration. Even if it were able to compac: the $10-\mathrm{ft}$ clay blanket above it would provent the upward flow of pore water needed for liquefaction. Thus neither of the conditions for liquefaction exist.

A worst casc cxamination was conducted, using the soil prorile ghown in Fig. 6. This profile meets the necessary conditions for liquefaction. Then we analyzed this profile using a procedure developed by Seed and Idriss.

The procedure is based on the concept that shear stress developed $n$ a soil

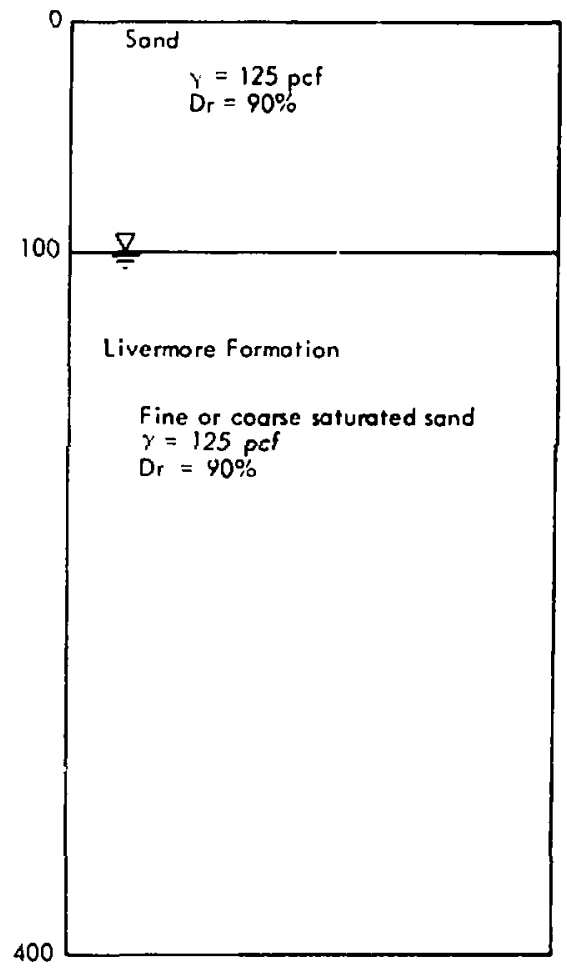

Fig. 6. Assumed worst case soil profile at LPTR site.

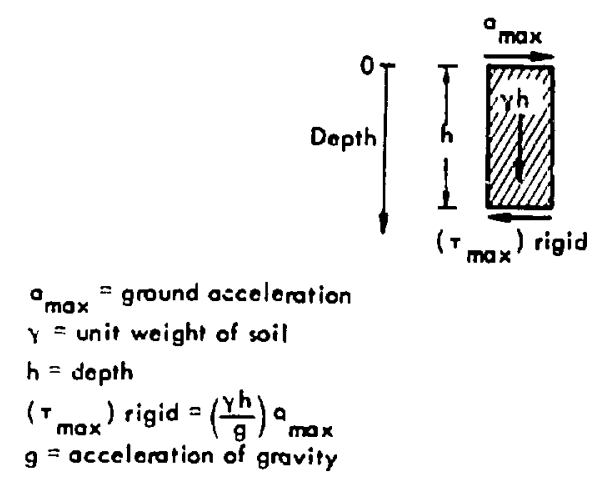

Fig. 7. Rigid soll column subjected to ground acceleration.

deposit are due to an upward-propagating shear wave. First, maxinium stresses: induced by the earthquake are calculated based on a rigid soil column as shown in Fig. 7. The shear stress is then corrected to account for the deformable nature of the soll by introducting the strees reduction factor $r_{d}$. Laboratory tests show the average shear stress to be $\approx 65 \%$ of the maximum shear stress. Hence the average shear stress induced in the soll deposit during an earthquake is

$\left({ }^{\top} \mathrm{av}\right)_{\text {deformable }}=0.65\left(\frac{\gamma h}{\mathrm{~g}} \mathrm{a}_{\max }\right) \mathrm{r}_{\mathrm{d}}$

Next, the stresses needed to cause liquefaction must be calculated. Cyclic loading triaxial compression test data was used to obtain a laboratory stress ratio at liquefaction as a function of the grain size of the sand. These tests were all conducted at a relative density of $50^{\circ}$. The laboratory values are then corrected for relative density $\left(D_{r}\right)$ and related to field data with a correction factor $C_{r}$. 
The stress int o in the field is then furth by the equation

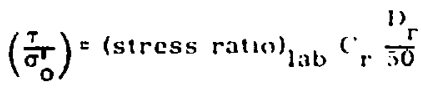

where

$\tau=$ shear stress needed for lwuthactum $\sigma_{0}^{\prime}=$ initial effective overburden pussure.
Thus the stressedes needed lo coluse liquefaction maly be estumaled by

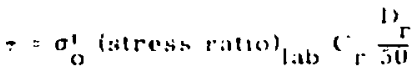

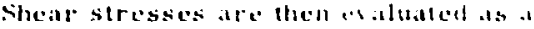
function of depth from lias. 11 ind (2) and plotted. If in oreelap oceurs in the

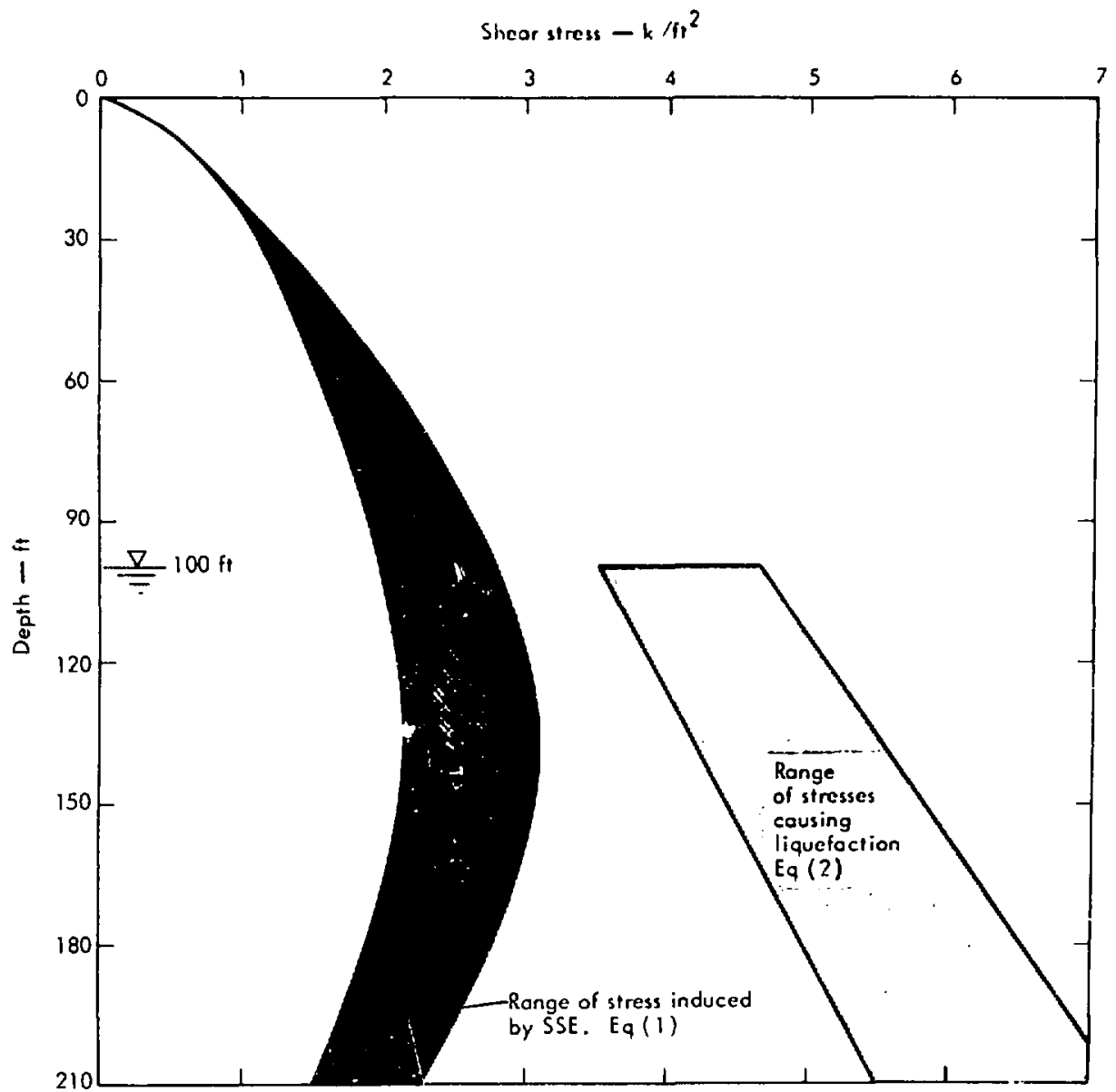

Fig. 8. Evaluation of soil liquefaction potential (worst case) with ground waler table at $100 \mathrm{st}$. 
plot a porentialliquefaction problem exists at the site. These stresses are plotted in Fig. 8. Sunce there is mo overlap, no potential for liquefaction exists.
Hased on the current knowledge of the soil conditions and the location of the grouncl water table at the LLL sitce, liquefaction is not a problem.

\section{Soil-Structure Interaction Effects}

The structural anaiyes to be discussed in the rollowing sections are based on an analytical model that issumes a fixed base condtition at ground level. The purposc of this section is to determine whether including the soil beneath the facility affects the ralculated response of the reactor shield.

Soil-structure interaction generally affects boin the horizontal and vertica! motions at the base of the structure. One affect of the underlying suil will probably be to reduce the shield stresses, mainly dise to the high damping prosided by the soil. A more important aspect is the pessible introduction of rocking and trinslation of the structure, a ropic that "ill occupy the remainder of this section.

The reactor shicld was assumed to be rigid and the effect of the soil was modeled as a translational and lorsional spring. The values of the spring constant were determined from results derived for

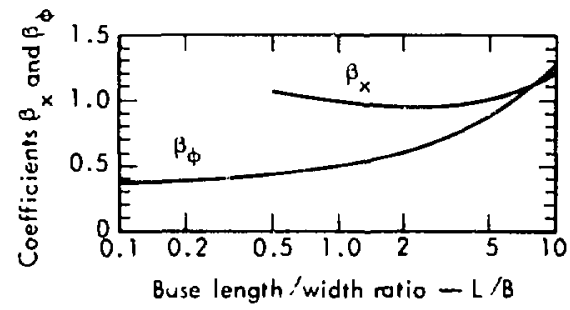

Fig. 9. Coefficients $\beta_{X}$ and $B_{4}$ for rectangular footing (from Ref. 9). elastic half-spaces. 9 The following equations were used for the eranslational and torsional spring constants:

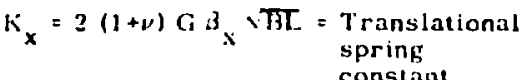

$$
\begin{aligned}
& K_{\theta}=\frac{G}{l-l^{\prime}} a_{C} B 1^{2}=\text { Torsional } \\
& \text { spring } \\
& \text { constant }
\end{aligned}
$$

where:

$$
\begin{aligned}
& G=\text { Shear modulus of soil } \\
& t=\text { Poisson's ratio of soil } \\
& B=\text { Erfectue foundation width } \\
& \text { (l to applied force) } \\
& \text { I. = Effective loundation length } \\
& \text { (' (w) applied force) } \\
& B_{\mathrm{X}}, B_{\epsilon}=\text { Pirameler determined as a }
\end{aligned}
$$

Sinil properties used to determine the spring constant are $G=5 \times 10^{6} \mathrm{lb} / \mathrm{ft}^{2}$. obtainable irom the site soil properties. and an assumed Poisson's ratio of $\nu=?$ i.

The effect of earthquake loading was modeled by placing a lateral load at the center of gravity of the shield. The magnitude of the lateral load was determined from $\mathrm{F}=\mathrm{Ma}=0.5 \mathrm{M} \mathrm{g}=0.5 \mathrm{~W}$, where

$\mathrm{a}=0.5 \mathrm{~g}=$ peak acceleration irom SSE spectra for calculated period of fixed base model $\{\mathrm{T}=0.020 \mathrm{sec}$. 
g = acceleration of gravity

$M=$ mass of shield

$W=M_{g}=$ weight of shield.

A static analysis of the model shown

in Fig. 10 results ir. expressions for the maximum rocking and maximum translational displacement of

$$
\underset{\substack{\text { maxking } \\ \text { rocking }}}{\Delta_{\phi}}=\frac{(0.5 W)(H)(h+q)}{K_{\phi}}
$$

$$
\Delta_{\text {max }}=\frac{0.5 W}{K_{\lambda}}
$$

Estimates of maximum displacements due to rocking and translation in the NorthSouth and East-West directions were conducted. Results appear in Table 2. Since these displacements were within acceptable limits no further analysis was necessary.

Estimates of the fundamental period of vibration of the reactor shield with rocking and translation were made by applying Dunkerley's Formula 10,11

$$
r=\sqrt{T_{f b}^{2}+T_{t}^{2}+T_{r}^{2}}
$$

where

$T=$ Fundamental period of shield with soil-structure interaction

$\mathrm{T}_{\mathrm{fb}}=$ Fundamental period of fixed base model

$T_{t}=$ Fundamental period due to ground translation alone

$T_{r}=$ Fundamental period due to ground rocking alone

The periods of ground translation and rocking can be expressed as 10

$$
T_{t}=2 \pi \sqrt{\frac{W}{g} \cdot \frac{l}{K_{x}}}
$$

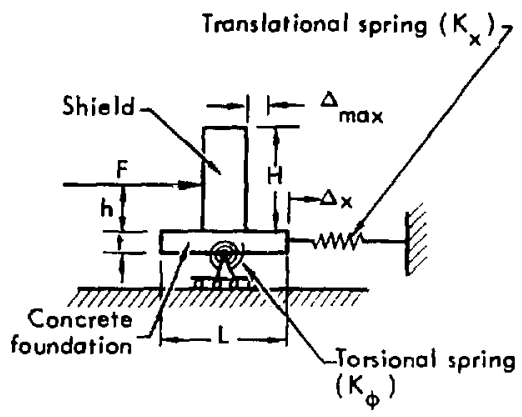

Fig. 10. Model of reactor shield for estimating rockilı and transla-

\begin{tabular}{|c|c|c|c|c|c|c|c|c|c|c|}
\hline $\begin{array}{l}\text { Earthquake } \\
\text { direction }\end{array}$ & $\begin{array}{l}\text { Effe } \\
\text { louno } \\
\text { dimen } \\
\text { for ro } \\
\text { B(ft) }\end{array}$ & $\begin{array}{l}\text { ctive } \\
\text { dation } \\
\text { sions } \\
\text { cking } \\
\text { Lfft) }\end{array}$ & $\begin{array}{r}\text { Effe } \\
\text { foun } \\
\text { dime } \\
f \\
\operatorname{trans} \\
\bar{B}(f \bar{t})\end{array}$ & $\begin{array}{l}\text { ctive } \\
\text { ation } \\
\text { sions } \\
\mathbf{r} \quad b \\
\frac{\text { ation }}{\text { L(ft) }}\end{array}$ & $B_{\phi}$ & $\begin{array}{c}K_{\phi} \\
\left(\frac{\mathrm{ft}-1 \mathrm{~b}}{\text { radian }}\right)\end{array}$ & ${ }^{3} \times$ & $\begin{array}{c}\mathrm{K}_{\mathrm{x}} \\
(\mathrm{lb} / \mathrm{ft})\end{array}$ & $\underset{\substack{\max \\
\text { rocking } \\
\text { (in.) }}}{\Delta}$ & $\underset{\max }{\Delta_{\text {translation }}}$ \\
\hline North-South & 30 & 20 & $4 j$ & 30 & 0.45 & $45.0 \times 10^{9}$ & 1.0 & $6.0 \times 10^{8}$ & 0.044 & 0.008 \\
\hline East-West & 20 & 30 & 30 & 45 & 0.55 & $82.5 \times 10^{9}$ & 1.0 & $6.0 \times 10^{8}$ & 0.025 & 0.008 \\
\hline
\end{tabular}
tional displacement.

Table 2. Estimates of maximum lateral displacement of reactor shield due to rocking and translation.

\footnotetext{
${ }^{a}$ Actual concrete pad dimensions.

b, 1.5 times actual concrete pad dimensions. These dimensions were increased due to the confinement provided by adjacent foundations of ather structures within the coltainment building.
} 


$$
T_{r}=2 \pi \sqrt{\frac{W}{R} \cdot \frac{1}{32.8 K_{x}}}
$$

where:

$$
\frac{W}{g}=\text { mass of reactor shield }
$$

The calculated perlod with ground interaction was $T=0.0 .45 \mathrm{scc}$. Examina- tion of the SSE spectra show s that this increase in fundamental period causes no dynamic amplification. This justifies the assumption of peate ground acceleration acting on the reactor shield for rocking and translational displacements and the use of a fixed based model for seis mic analysis.

\section{Reactor Shield Analysis and Results}

The reactor shield, shown in Fig. 1, wos analyzed using the finite element method. The analysis wrs performed using the computer code, GHOSH. 12,13 The shield was modeled as an axiaymmetric structure about its weak axis. Figure 11 shows the finite element mesh used. Both the standard and heavy concrete were represented as solid elements. The aluminum pool tank was idealized with shell elements. The shield was considered rigidly connected to the foundation. The materials properties used in the analysis ${ }^{14,15}$ appear in Table 3.

The model was subjected to dead load, and horizontal and verticai components of the SSE carthquake loading. Hydro- static pressure and hydrodynamic effect of the water in the pool tank were neglected.

The ten low sat fundamental modes of vibratton were used for horizontal response. Only five modes were needed to calculate the vertical response. Table 4 gives the first three periods of vibration for both horizontal and vertical responses.

The results from both the dead load and the earthquake loads are plotted in Figs. 12-17. Figures 12 and 13 show maximum calculated horizontal and vertical displacements of 0.0075 and 0.005 in., respectively, at the top of the shield. Figures 14 and 15 show the shield in its maximum deflected position (magnified 4000 times) for both the

\begin{tabular}{|c|c|c|c|c|}
\hline Material & $\begin{array}{l}\text { Modu:us } \\
\text { of } \\
\text { elasticity } \\
\left(10^{6} \text { psi }\right)\end{array}$ & $\begin{array}{c}\text { Poisson's } \\
\text { ratio }\end{array}$ & $\begin{array}{c}\text { Unit } \\
\text { weight } \\
\left(\mathrm{lb} / \mathrm{ft}^{3}\right)\end{array}$ & $\begin{array}{c}\text { Mass } \\
\text { density } \\
\left(\begin{array}{c}10^{-4} \\
\left(\frac{10-\sec ^{2}}{\text { in. }^{4}}\right)\end{array}\right.\end{array}$ \\
\hline Standard concrete & 3.30 & 0.17 & 150 & 2.25 \\
\hline Heavy concrete & 5.00 & 0.20 & 225 & 3.37 \\
\hline Aluminum & 10.6 & 0.33 & - & 2.59 \\
\hline
\end{tabular}

Tabie 3, Material properties used for shield analysis.

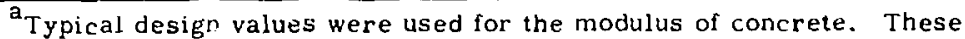
values were not increased to simulate improvement of properties with age. 


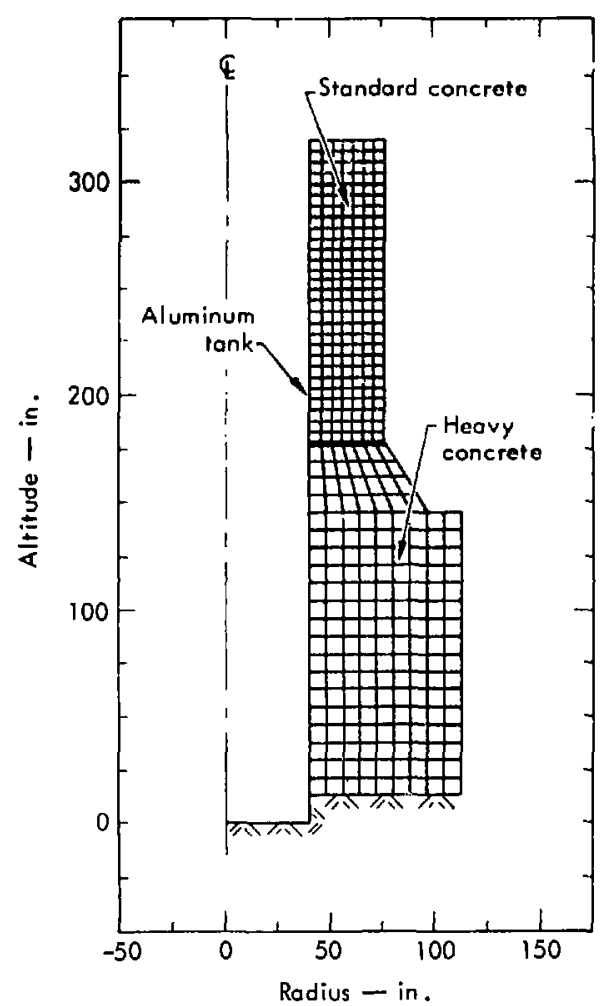

Fig. 11. Computer model of LPTR shield and aluminum tank.

Table 4. Luwest vibration periods of reactor shield.

\begin{tabular}{cc}
\hline Mode & $\begin{array}{c}\text { Period } \\
\text { sec }\end{array}$ \\
\hline $\begin{array}{c}\text { Horizontal } \\
1\end{array}$ & 0.0200 \\
2 & 0.0091 \\
3 & 0.0048 \\
Vertical & \\
1 & 0.0073 \\
2 & 0.0038 \\
3 & 0.0033 \\
\hline
\end{tabular}

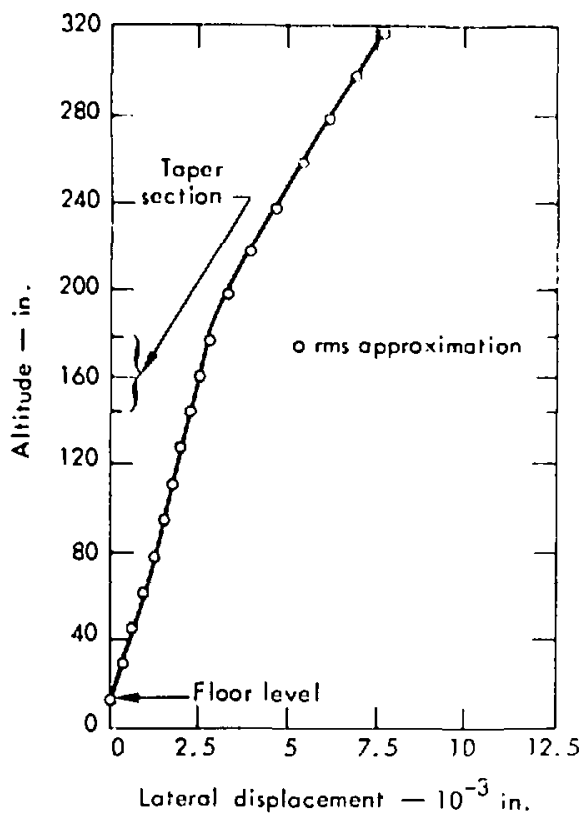

Fig. 12. Lateral displacement at oute: surface of L.PTR shield, horizontal and vertical SSE.

horizontal and vertical component of the SSE loading. Figures 16 and 17 give the variation of the calculated maximum stresses with height in the reactor shield. A maximum vertical compressive stress of 158 psi was caloulated at the interface between standard and heavy concr te. This is well below the 3000 psi compressive strength of the concrete.

The maximum shear stress in the shield is 50 psi. (See Fig. 17.) The allowable shear stress for concrete having a compressive strength of 3000 psi is 60 psi. 16

Tensile stress were assumed carried solely by the steel reinforcement. Details of the reinforcement in the shield appear in Fig. 18. Regions of large 


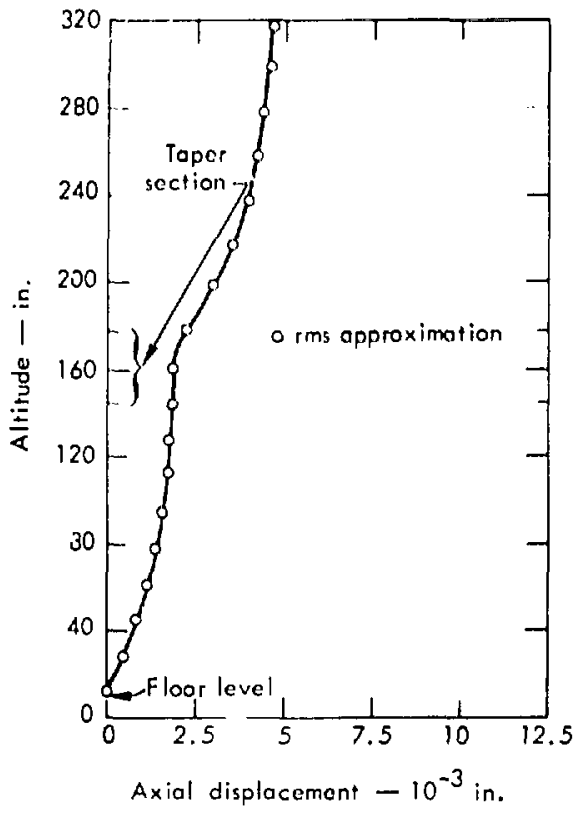

Fig. 13. Vertical displacement at nuter surface of LPTR shield, horizontal and vertical SSE.

vertical stress occur at the cunnection to the foundation and at the standard concreteheavy concrete interface. An overlap of reinforcement in these areas provides for these stress concentrations. The maximum tensile steel stre. ses throughout the shield are always bolow ultimate values for A-15 hard grade billet steel. (Yield stress $=50 \mathrm{ksi}$, ultimate stress $80 \mathrm{ksi}$.) Typical values of the steel stresses are also shown in lig. 18.

The displacements resulting from the earthquake motions are very small. The concrete alone has adequate strength to carry the shear and compressive stresses. No yielding of the horizontal steel and some yielding of the vertical steel is expected to result from the combined deadlond and earthquake loading.

The vertical streys distributions at the reactor shield foundation due to dead lond and earthquake londing are shown in Fig. 19. The distributions due to the dead load ard the vertical earthquake component are axisymmetric: the distribution due to the horizontal component

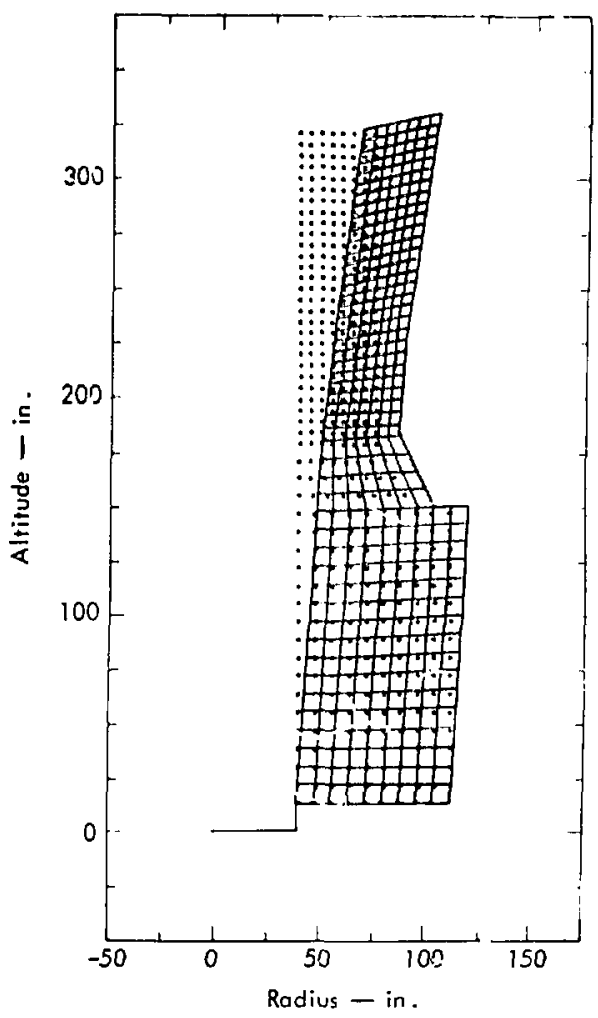

Fig. 14. Deformed shape of L.PTR shieid and aluminum tank, using rms cpproximation, resulting from 'orizontal component of SSE. Lisplacement amplification, $\times 4000$. (Dots indicate unstressed pusition.) 

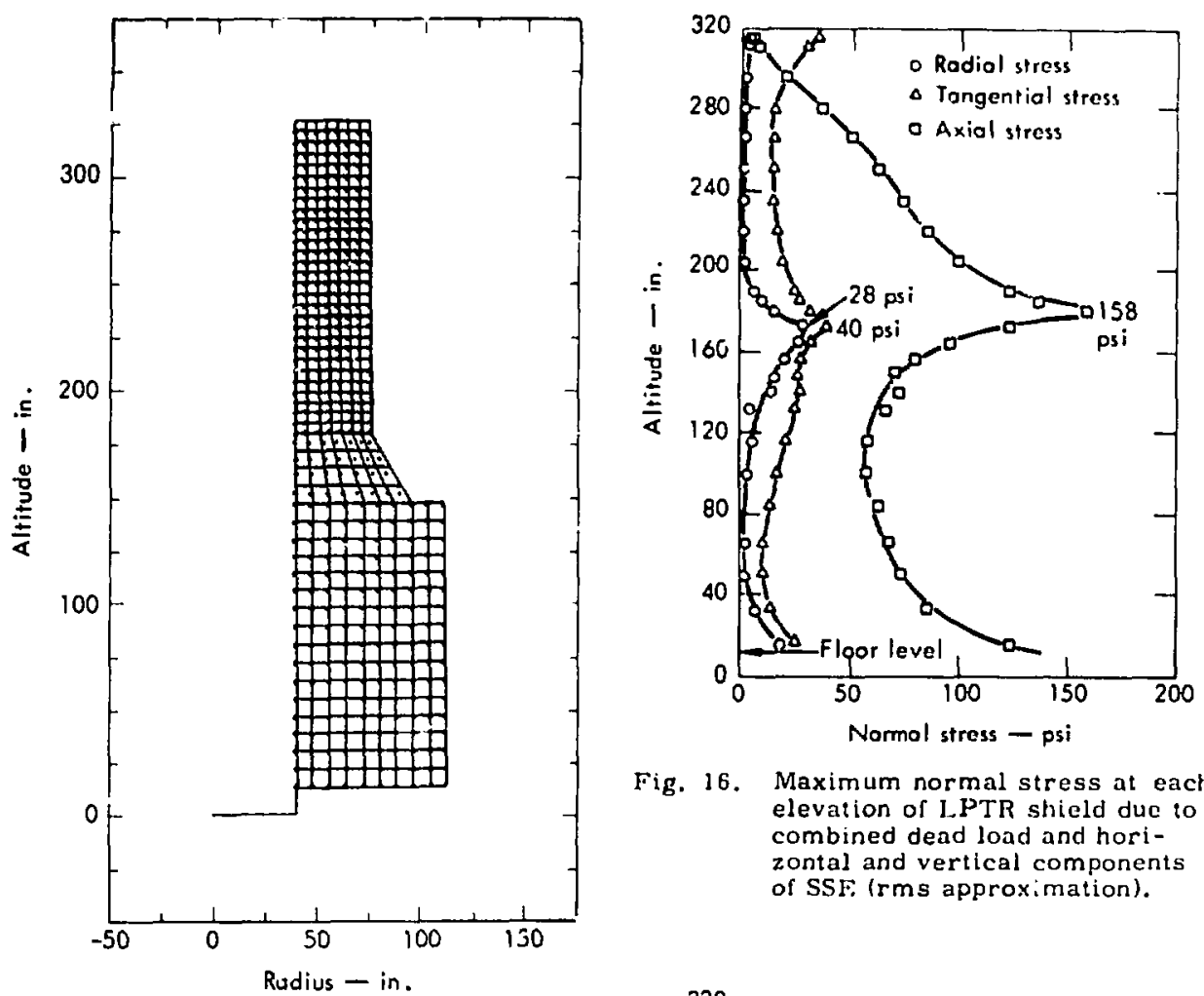

Fig. 16. Maximum normal stress at each elevation of LPTR shield due to combined dead load and horizontal and vertical components of SSF (rms approximation).

Fig. 15. Deformed shape of LPTR shield and aluminum tank, using rms approximation, resulting from vertical component of SSE. Displacement amplification, $\times 4000$.

Fig. 17. Maximum shear stress at each elevation of LPTR shield due to combined dead load and horizontal and vertical components of SSE (rms approximation).

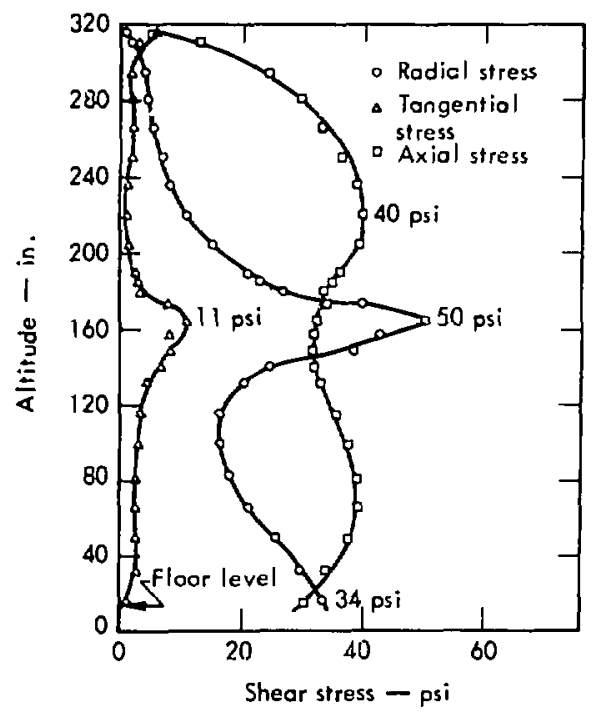


Properties of A15-50 reinforcing steel

$\sim \sigma$ yield $=50 \mathrm{ksi}$

$-\sigma$ ultimate $=80 \mathrm{ksi}$

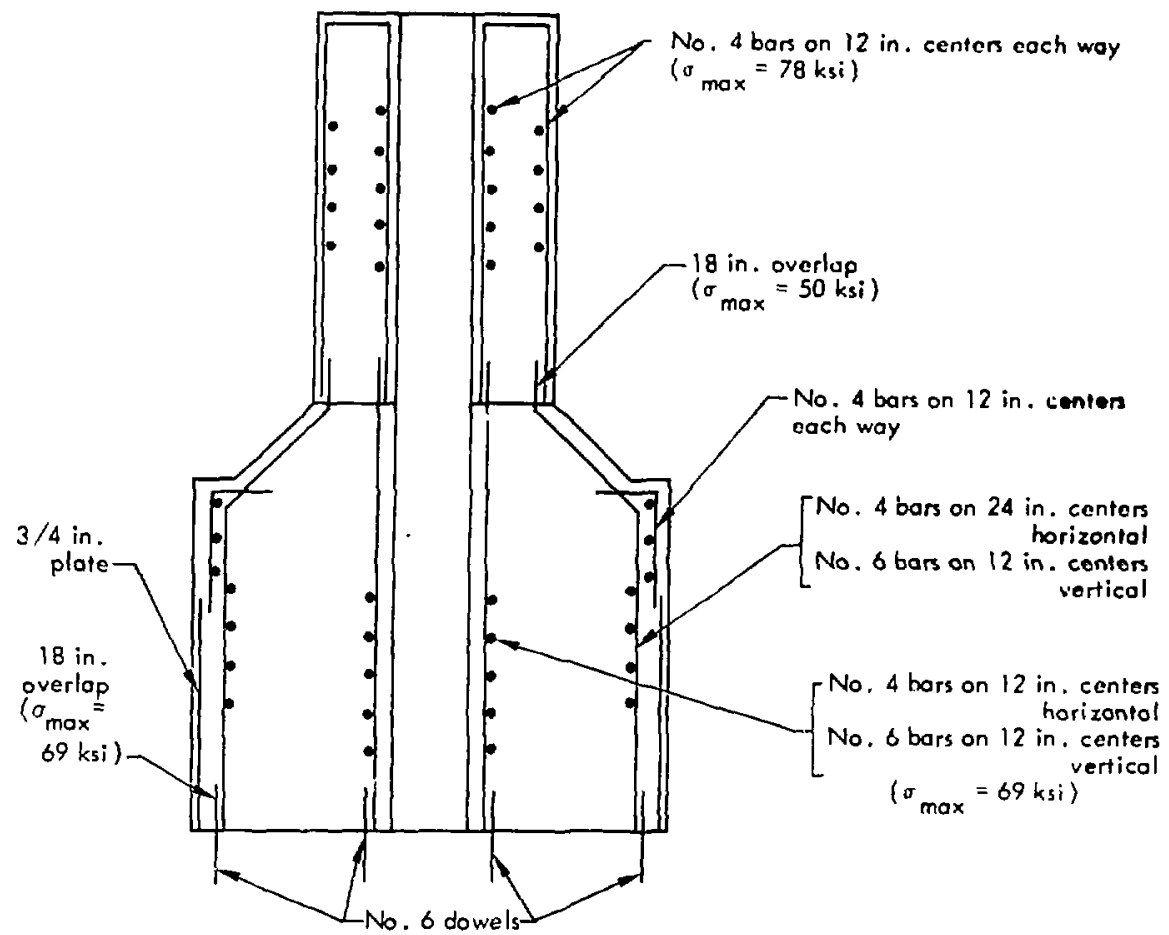

Fig. 19. Reactor shield reinforcement details and calculated steel stresses.

varies as the cosine of the angle between the earthquake direction anci the position of interest.

Figure 20 shows the maximum combined compressive stress distribution. These maximum values assume that both earthquake components combined with the dead load to give the largest compressive values. A maximum compressive stress of 200 psi was obtained. This is well below 3000 psi, the crushing strength of the concrete.
The maximum earthquake and dead load stresses were also combined in such a way to produce the maximum tension stresses at the reactor shield base. (See Fig. 2i.)

An array of No, 6 bars distributed over its base ties the shield to the foundation. Twenty-two bars are evenly spaced at a 43 -in. radius and 68 at a $96-i n$. radius. These bars are assumed to carry all of the tensile stress at the base.

In order to simplify the calculation and still arrive at a reasonable evaluation 
Rodius - in.

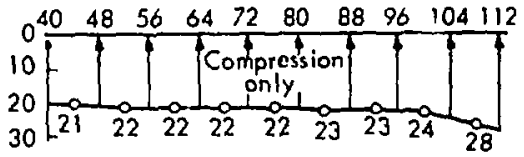

Dead load
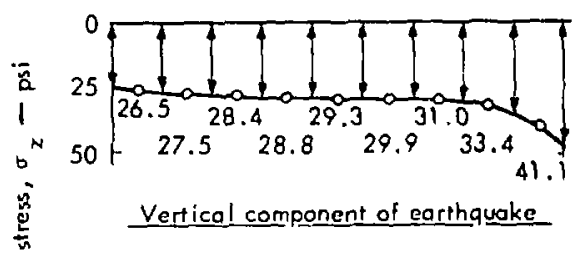

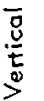

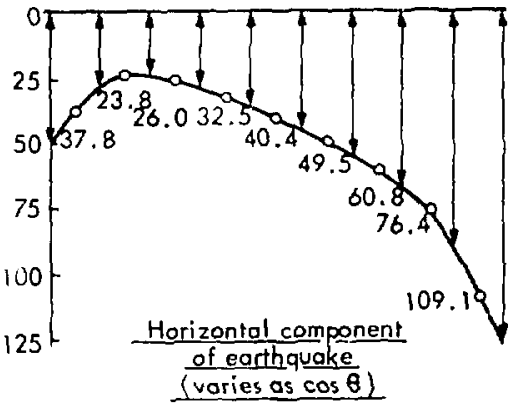

Fig. 19. Axial stress distribution at base of I.PTR shield due to dead load and SSE components.

of the ability of these bars to resist tensile stresses, the average stress distribution shown in Fig. 21 was assumed. The assumption that this stress distribution is axisymmetric yielded tensile stresses of 55 and $65 \mathrm{ksi}$ on the inner and outer circles of bars. These bars have a yield strength of $50 \mathrm{ksi}$ and an ultimate strength of $80 \mathrm{ksi}$.

The ability of these bars to develop sufficient bond was also checked. The results indicated a maximum bond strength of 923 psi with a maximum bond stress of 900 psi. ${ }^{16}$ Since there is adeguate bond some yielding of the bars would take place if both earthquake components combined in this worst case sttuation.

The maximum shear stress in the concrete at the base is 34 psi from Fig. 17. The base shear force was computed on the assumption that this shear force is distributed equally over all 90 bars. This results in a shear stress of $29.5 \mathrm{ksi}$ in each bar. This valuc is slightly greater than the shear yield stress $\left(\tau_{\text {yield }}=50 \mathrm{ksi} / \sqrt{3}=29 \mathrm{ksi}\right)$. Thus some yiclding of the bars is expected.

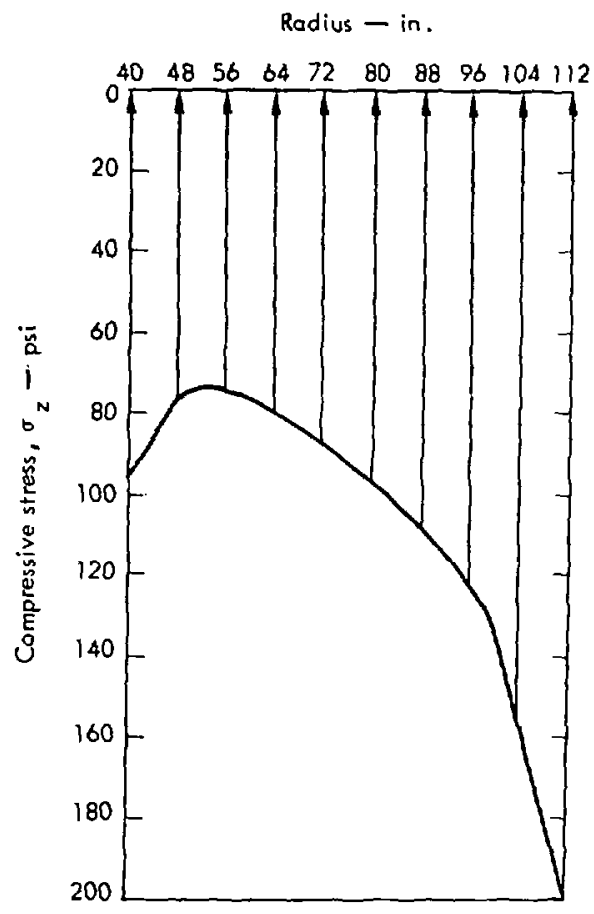

Fig. 20. Maximum compressive stress distribution at LPTR shield base, i. e., sum of horizontal, vertical, and dead loads. 


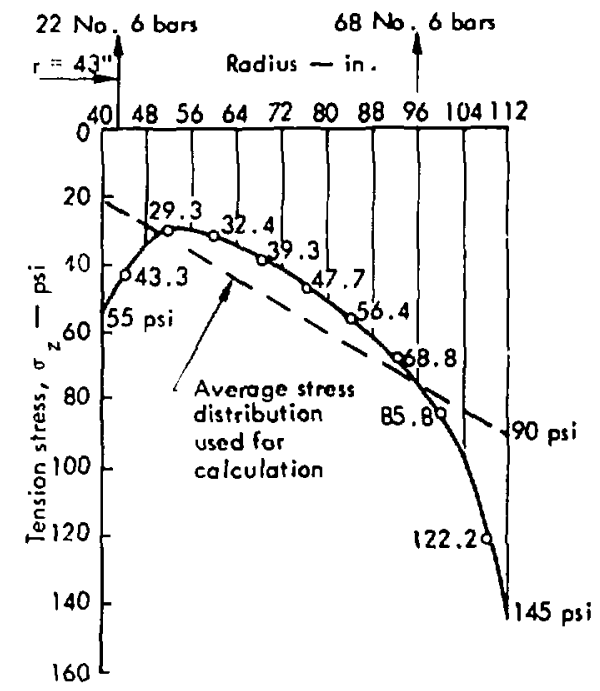

Fig. 21. Maximum tension stress distribution at LPTR shield base, i. e. horizontal plus vertical minus dead load.

Other means of transferring the shear load at the base include mechanical inter. ference due to the key and friction between the foundation and shir!f. Since these were not considered in the analysis, the above results are conservative.

\section{Containment Building Analysis and Results}

We conducted a linear elastic analysis of the coniainment building using the finite element method. The building was represented as the axisymmetric structure shown in Fig. 22 and subjected to dead load, 2 psi internal pressure (which could result from atmospheric conditions), and horizontal and vertical components of the SSE. The computer program GHOSH 12,13 was used.

A finite element mesh consisting of shell elements was used to model the steel structure. Solid elements connected to the siall at five locations simulated the affect of stiffeners in the actual structure. The mass density of the steel was increased to include the effect of insulation weight. The building was considered rigidly connected to its foundation.

Shell thicknesses were varied to model the different thickness of the shell and roof. Lap joints were included by increasing the thickness at the joints. 


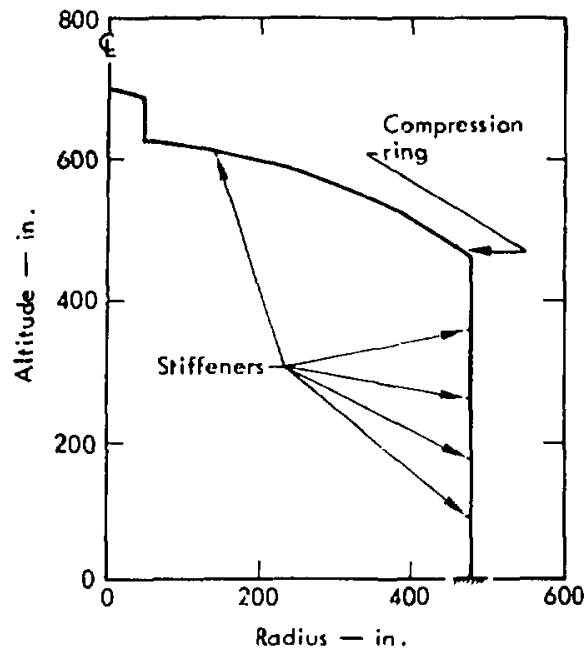

Fig. 22. Computer model of LPTA containment building.

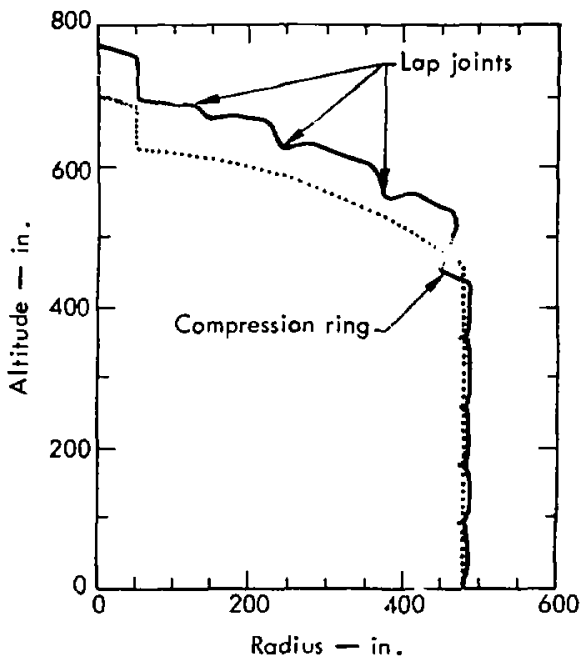

Fig. 23. Deformed shape of LPTR containment building, 2 psi internal pressure. Displacement amplification, $\times 100$. (Dots indicate unstresseci position.)
The compresston rinf located at the rous connection was included as a thacker shell. locally stiffening the shell-roof connection.

Ten mories of vibration were used to determine both horizontal and vertical response to the carthquake loading. The first three periods appear in Table 5.

Figure 23 shows the displaced shape of the stricture, amplified ino times, when subjected to dend lond and 2 psi internal pressure. Figures 24 and 25 show horizontal and vertical displacements

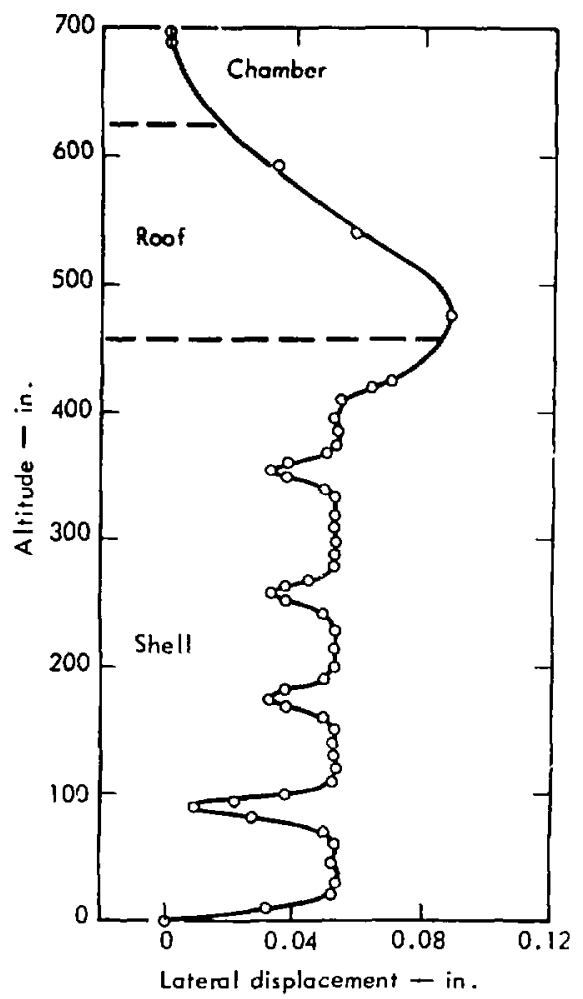

Fig. 24. Lateral component of displacement of LPTR containment building under 2 psi internal pressure. 
due to the pressure loading. Maximum horizontal and vertical displacements are $0.090 \mathrm{in}$. and $0.075 \mathrm{in}$. respectively.

stresses in the shell and roof for the pressu -e loading are well within allowable design values for ASTM A-283 steel piates. Compare the design values of yield strength ( $33 \mathrm{ksi})$ and ultimate strength (55 ksi) with the calculated stresses shown

Table 5. Containment building lowest periods of vibration.

\begin{tabular}{ccc}
\hline \multicolumn{2}{c}{ Mode } & $\begin{array}{c}\text { Period } \\
\text { (sec) }\end{array}$ \\
\hline \multirow{2}{*}{ Horizontal } & 1 & 0.055 \\
& 2 & 0.042 \\
Vertical & 3 & 0.041 \\
& 1 & 0.065 \\
& 2 & 0.040 \\
& 3 & 0.032 \\
\hline
\end{tabular}

in Table 6. Furthermore, the structure has been tested to an Internal pressure of 2 psi.

Figures 26 and 27 show the displaced shape for the horizontal and vertical components of the SSE. These shapes have been amplified by factors of 320 and 600 respectively.

Figures 28 and 29 show t'ie horizontal and vertical displacements combined for both components of the SSE. A meximum lateral displacement of $0.135 \mathrm{in}$. and a maximum axial displacement of 0.156 in. were calculated.

Stresses induced by the earthquake components are approximately $10 \%$ of the stresses resulting from the pressure loading. No problems are expected in the containment building.

Table 6. Shell and roof stresses.

\begin{tabular}{|c|c|c|c|c|c|c|}
\hline \multirow{3}{*}{$\begin{array}{l}\text { Altitude } \\
\text { (in.) } \\
\end{array}$} & \multicolumn{3}{|c|}{ Hoop stress (ksi) } & \multicolumn{3}{|c|}{ Axial stress (ksi) } \\
\hline & \multirow{2}{*}{$\begin{array}{l}\text { Static } \\
\text { loads }\end{array}$} & \multicolumn{2}{|c|}{ Earthquake } & \multirow{2}{*}{$\begin{array}{l}\text { Static } \\
\text { loads }\end{array}$} & \multicolumn{2}{|c|}{ Earthquake } \\
\hline & & Horizontal & Vertical & & Horizontal & Vertical \\
\hline \multicolumn{7}{|l|}{ Shell } \\
\hline 45 & 3.88 & 0.025 & 0 & 2.00 & 0.500 & 0.165 \\
\hline 130 & 3.88 & 0.050 & 0 & 1.98 & 0.425 & 0.165 \\
\hline 214 & 3.86 & 0.065 & 0 & 1.96 & 0.365 & 0.150 \\
\hline 299 & 3.86 & 0.090 & 0 & 1.94 & 0.290 & 0.150 \\
\hline 385 & 3.89 & 0.100 & 0 & 2.88 & 0.240 & 0.150 \\
\hline \multicolumn{7}{|l|}{ Roof } \\
\hline 476 & 7.47 & 0.150 & 0.450 & 5.43 & 0.515 & 0.390 \\
\hline 535 & $6.3 B$ & 0.540 & 0.415 & 5.93 & 0.525 & 0.525 \\
\hline 597 & 5.44 & 0.390 & 0.475 & 3.18 & 0.225 & 0.290 \\
\hline 621 & 2.84 & 0.525 & 0.375 & 1.45 & 1.390 & 0.475 \\
\hline
\end{tabular}

${ }^{\mathrm{a}}$ Dead load plus 2 psi internal pressure.

Steel Plates (ASTM-A283)

$$
\begin{aligned}
& \sigma_{\text {yield }}=33 \mathrm{ksi} \\
& \sigma_{\text {ultimate }}=55 \mathrm{ksi}
\end{aligned}
$$




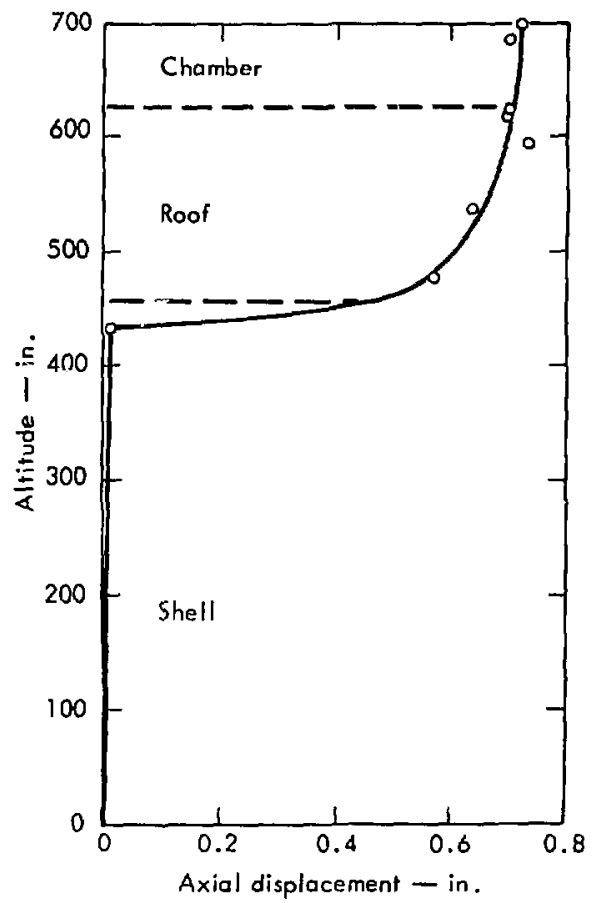

Fig. 25. Axial component of displacement of LPTR containment building unter 2 psi internal pressure.

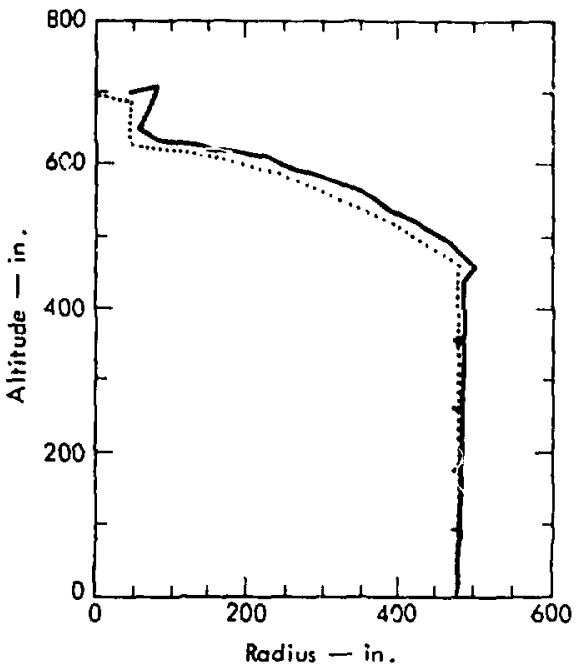

Fig. 26. Deformed shape of I PTR containment building, using rms approximation, resulting from horizontal component of SSE. Displacement amplification, $\times 320$.

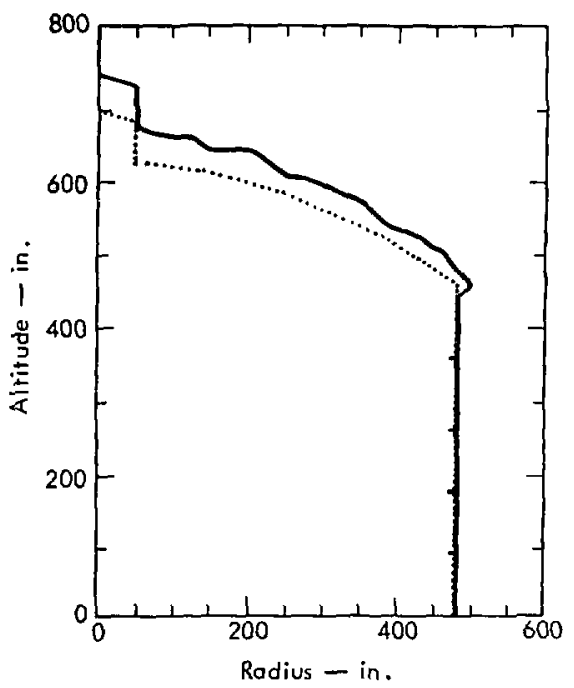

Fig. 27. Deformed shape of LPTR containment building, using rms approximation, resulting from vertical component of SSE. Displacement amplification $\times f 00$. 


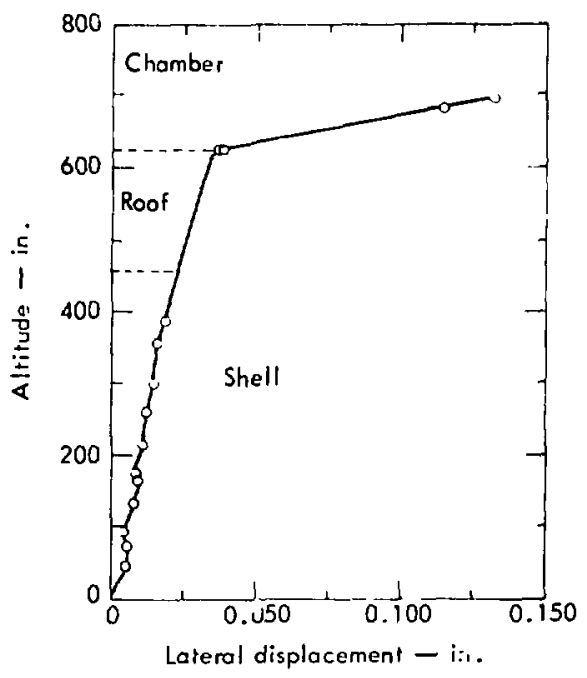

Fig. 28. Lateral component of displacement of LPTR containment building from combined horizontal and vertical components of SSE (rms approximation).

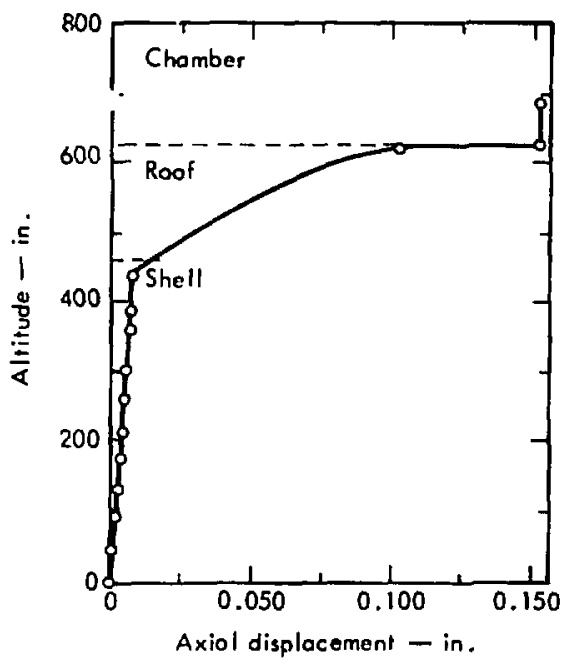

Fig. 29. Axial component of displacement of LPTR containment building from combined horizontal and vertical components of SSE (rms approximation).

\section{Other Category I Structural Analyses and Results}

\section{OVERHEAD BRIDGE CRANE SUPPORT STRUCTLRE}

The first step of the analysis was the determination of maximum hook loading. We considered only weights (masses) that would be lifted to the top of the overhead bridge structure, neglecting masses lifted only slightly from the floor. The maximum expected crane hook load was determined from the actual past loading history. Although the crane has a capacity of $30 \mathrm{kip}$, past records of crane usage indicate the maximum load raised to the top of the structure is $7 \mathrm{kip}$. This load occurs three times annually for short durations. Therefore, for the analys is of the crane support structure a 7-kip luve load was selected.

Step 2 was the determination of the worst case combination of hook position and earthquake direction, using the computer code TABS. ${ }^{17,18}$ The analysis indicated two worst case loading conditions, the structural and the nuclear. Case 1 (structural) locates the hook near the one quarter span point with the critical earthquake direction in the plane of the long span truss. Case 2 (nuclear) has the hook at midspan directly over the reactor pool tank. These luading conditions are shown on Fig. 30. Results also indicate that a planar analysis of the crane support structure in the long span direction would 


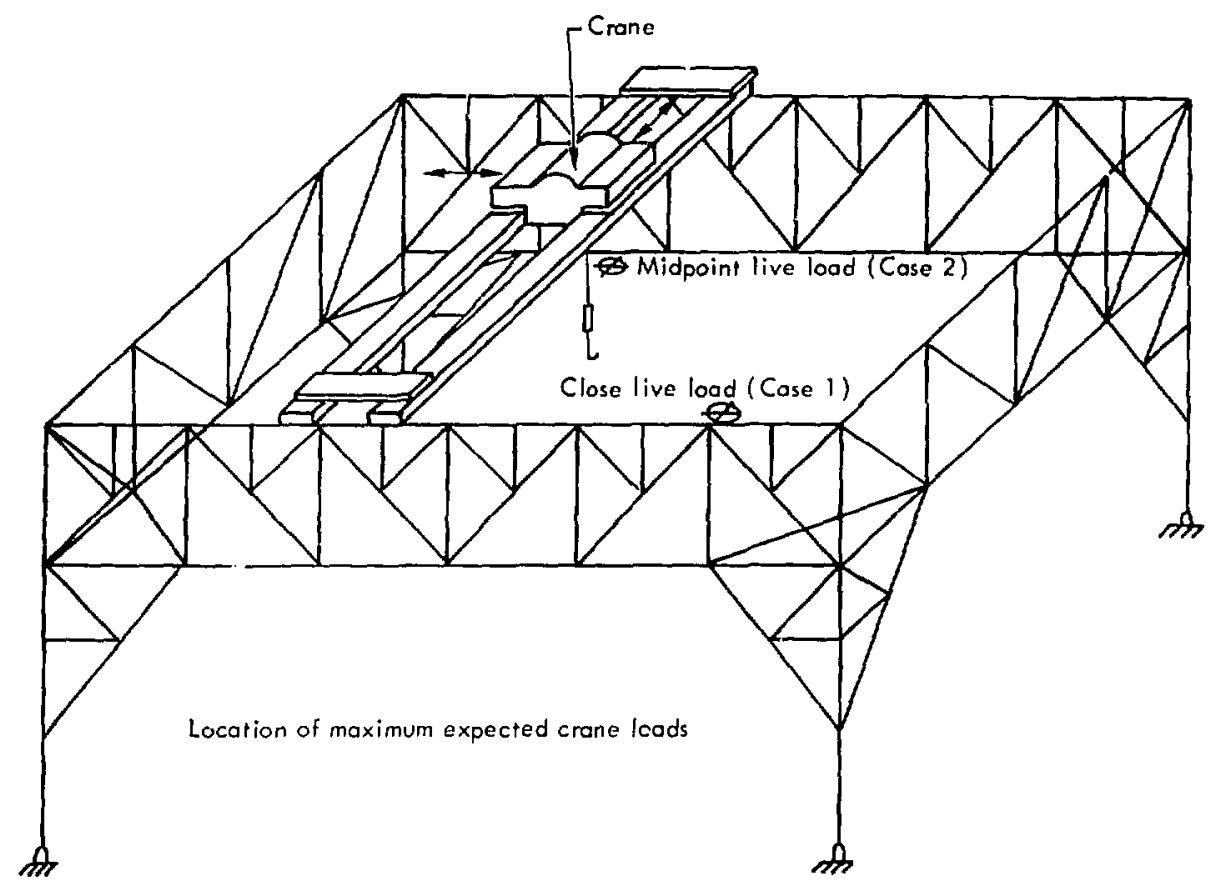

Fig. 30. LPTR bridge crane structure, showing location of worst case live loads.

adequately represent the actual structural behavior.

The remainder of the analysis consisted of a detailed elastic analysis of the long span frame with dead loads plus the $7 \mathrm{kip}$ maximum expected live load. The crane support was modeled as a plane rrame. The model used for this analysis is shown in Fig. 31. Properties of A-7 structural steel used in the analysis were $E=30,000 \mathrm{ksi}$, yield stress $=33 \mathrm{ksi}$, ultimate stress $=60 \mathrm{ksi}$. Examination of the member connection details suggested semirigid internal joints and pinned column connections ${ }^{19}$ at the base.

The frame analysis was conducted with the finite element program ${ }^{20}$ FRAMEa.
An estimate of the lateral stirfness of the irame, $K$, was determined as $14.9 \mathrm{kip} / \mathrm{in}$. The structure's fundamental period of vibration, 'T', was calculated by consiclering the frame as a single-degree-offreedom system with its mass lumped at the upper level. Spectral accelerations were obtained from Fig. 3 for $2 \%$ damping as a function of period. The response spectrum method was then used to determine the maximum lateral displacement.

Results of these calculations for both load cases are collected in Table 7 .

Member forces were then determined by conducting a static analysis of the plane frame subjected to the maximum lateral displacement $\Delta_{\max }$ and the loading conditions stated previously. 


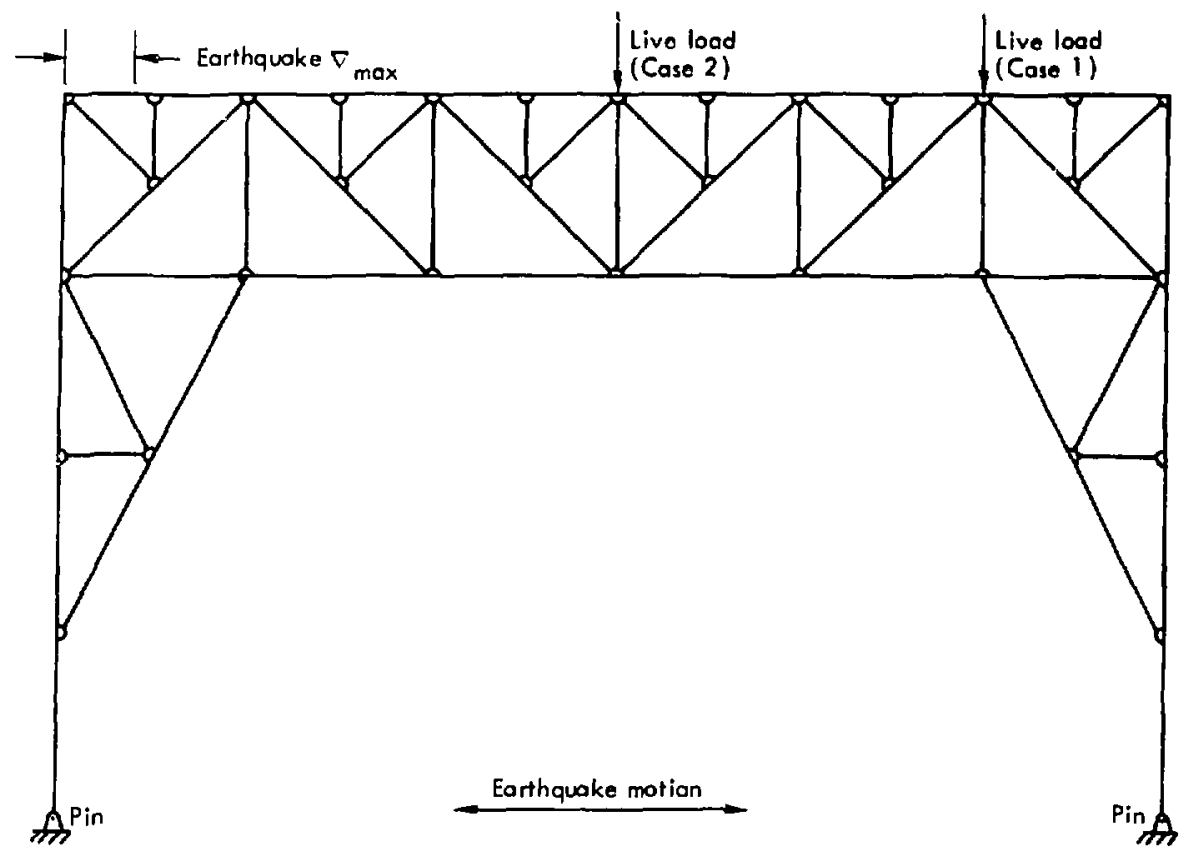

Fig. 31. Plane model of LPTR crane structure used in analyzing the response to the SSE under the two worst case loading conditions.

\section{Conclusions}

Lateral displacements of the structure are acceptable. (See Table 7.) A 5.5-in. clearance between the crane support structure and the containment building valls now exists.

Examination of the member forces for Case 1 indicates the anchor bolts at the pinned base plate connection are overstressed, extreme fiber stresses in the columns exceed ultimate values, and some secondary compression struts are overstressed. AISC allowable stresses in combined tension and shear for $\mathrm{A}-307$ bolts were used to evaluate the anchor bolts.

For Case 2 the anchor bolts exceed the allowable shear stresses and scme secondary struts are overstressed. Ultimate stresses are not excecded under this loading condition.

\section{Recommended Modifications}

Cover plates were designed that would reduce the stresses in the columns and braces during the earthquake loading. Figure 32 shows the details of the modification needed. A repeat analysis for Case 1 loading showed that the modified structure has a lateral stiffness of $36.1 \mathrm{kip} / \mathrm{in}$. and a furtamental perion of $0.27 \mathrm{sec}$.

At $2 \%$ damping a spectral acceleration of $772 \mathrm{in.} / \mathrm{sec}^{2}$ and a maximum lateral displacement of $1.5 \mathrm{in}$. were used as the earthquake loading conditions. For the 
Table 7. Summary of crane calculations.

\begin{tabular}{|c|c|c|c|c|c|}
\hline $\begin{array}{l}\text { Loading } \\
\text { condition }\end{array}$ & $\begin{array}{l}\text { Deaci load } \\
\text { plus max. } \\
\text { expected } \\
\text { load } \\
\text { W } \\
\text { (kip) }\end{array}$ & $\begin{array}{c}\text { Mass } \\
M=\frac{W}{B} \\
\left(\frac{\text { kip-sec }}{\text { in. }}\right)\end{array}$ & $\begin{array}{c}\text { Periud, } \\
\text { T } \\
\text { (sec) }\end{array}$ & $\begin{array}{c}\text { Spectral } \\
\text { acceleration, } \\
\left.\text { S }_{\text {aec }}{ }^{2}\right) \\
\text { (in., }\end{array}$ & $\begin{array}{l}\text { Max. lateral } \\
\text { displacement } \\
د_{\max }=\frac{M_{a}}{k}\end{array}$ \\
\hline Case 1 & $19.64^{a}+7=26.64$ & 0.069 & 0.43 & 733 & 3.4 \\
\hline Case 2 & $19.64^{a}+3.50=23.14$ & 0.060 & 0.40 & 772 & 3.1 \\
\hline
\end{tabular}

${ }^{a}$ Frame weight $=14.64 \mathrm{kip}$, crane hoist and trolley weight $=5.0 \mathrm{kip}$,

Total dead load $=19.64 \mathrm{kip}$.

structure modified as shown, all member and anchor bolt stresses were belcw acceptable values.

\section{REACTOR SHIELU TOP STRUCTLRE}

Figure 33 depicts the reactor shield top structure housine the contrul rod actuators and covering the top of the reactor pool. The structure is cantilevered from the concrete shield by two SWF 18.5 beams connected to the reactor shield by eight hooked anchor bolts 0.75 in. diam $\times 20$ in. long embedded in the concrete.

The top structure was modelled as a single-degree-of-freedom system, i.e., a lumped mass cantilevered from the reactor shield. A conservative estimate of 2000 pounds was made for the equipment and housing of the structure. The weight of the cantilever beams was neglected. The spectral response method was used to determine stresses and deflections. It was assumed that the SSE spectrum, transmitted unaltered by the shield, was applicable as a direct input for analysis.

The response of the top structure to both horizontal ano vertical components of the SSE was computed. Results of the analysis appear in Table 8 .
Table 8. Summary of top structure calculations.

\begin{tabular}{lccc} 
Enrthquake & $\begin{array}{c}\text { Cantlever } \\
\text { beam } \\
\text { gtiffnegs } \\
\text { (kip/ln.) }\end{array}$ & $\begin{array}{c}\text { Fundamental } \\
\text { pertod } \\
\text { (aec) }\end{array}$ & $\begin{array}{c}\text { Maximun } \\
\text { digplace } \\
\text { ment } \\
\text { (in.) }\end{array}$ \\
\hline North-bouth & 354 & 0.024 & 0.0028 \\
East-Weat & 8175 & 0.005 & 0.0001 \\
Vertical & 71 & 0.954 & 0.019 \\
\hline
\end{tabular}

Analysis of the anchor boli stress indicates they are well below allowable design values. A maximum tension stress of $9.07 \mathrm{ksi}$ and maximum shear stress of $2.115 \mathrm{ksi}$ for a typical anchor bolt was calculated. Allowable design values used for A-307 bolts under combined tension and shcar loadings are $14 \mathrm{ksi}$ in tension and $10 \mathrm{ksi}$ in shear.

HEAT EXCHANGER SUPPORT STRUCTURE

An analysis procedure similar to that conducted on the crane support structure was conducted on the heat exchanger support. The support structure was modeled as a pin ended frame with rigid joints. The stiffening effect of the connecting piping and the dead load of the stucture were neglected in the analysis. It was felt that a plane frame loaded as 


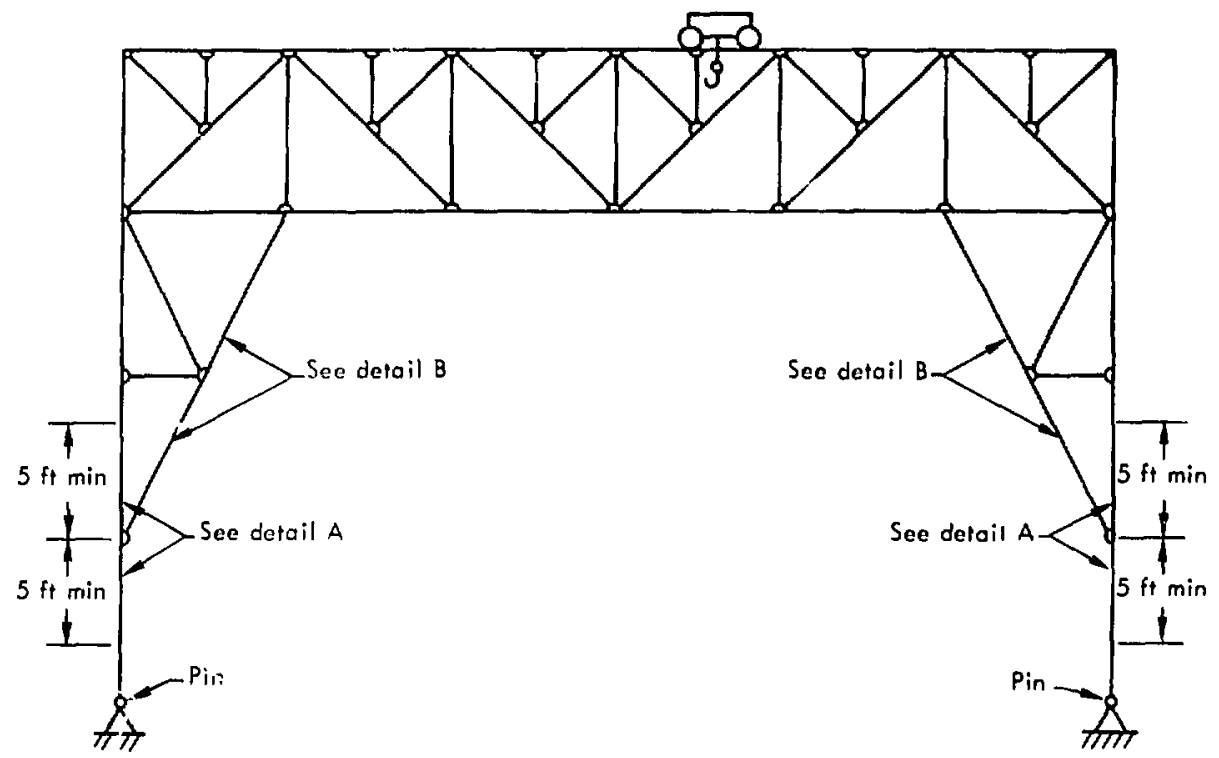

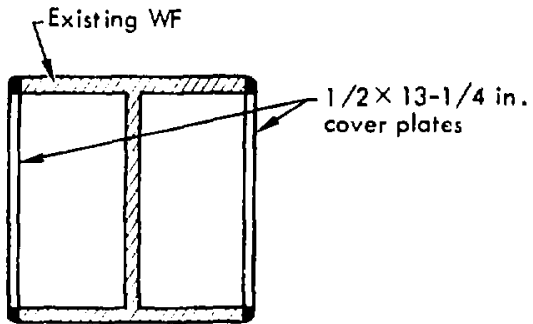

Detail A

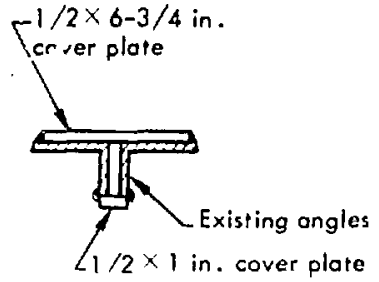

$\underline{\text { Detail B }}$

$$
\frac{\text { Earthquake motion }}{(\text { Eost-West direction })}
$$

Fig. 32. Suggested modifications to the LPTR crane support structure to improve resistance to lateral earthquake loads.

shown in Fig. 34 would adequately represent the three-dimensional structure. The total heat exchanger load of $10 \mathrm{kip}$ was distributed as shown on euch of two frames.

The structure lateral stiffness was determined as $3.5 \mathrm{kip} / \mathrm{in}$, Other calculated values include a mass of $0.013 \mathrm{kip}-\mathrm{sec}^{2} / \mathrm{in}$. and fundamental period of $0.38 \mathrm{sec}$. From Fig. 3 at $2 \%$ damping a spectral acceleration cí $790 \mathrm{in.} / \mathrm{sec}^{2}$ was determined which gives a corresponding maximum lateral displacement of 2.94 in.

Member forces were then determined by conducting a static analysis of the frame subjected to the heat exchanger dead load 


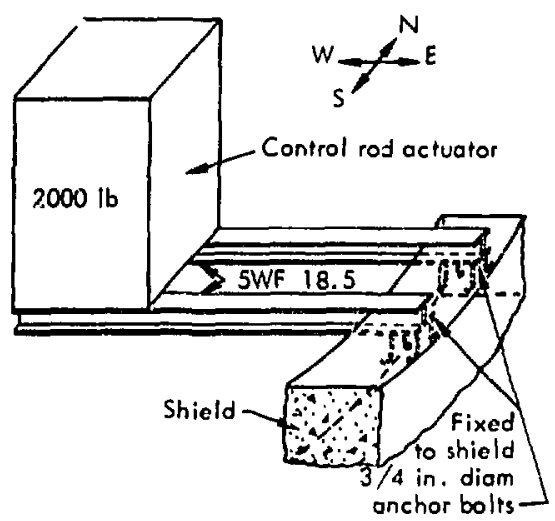

Fig. 33. Reactor shield top structure.

and the lateral displacement due to the earthquake.

\section{Conclusions}

Anchor bolt stresses exceed allowable design values and extreme fiber stresses in both beam and columns exceed ultimate values for A-7 structural steel.

The deficiencies in the structure can be corrected by adding cross bracing to the lege to increase the laceral stiffness of the support.

\section{Recommended Modification}

An analysis was conducted with cross bracing to determine an adequate member size to reduce stresses to allowable values. The cross bracing war rigidly connected to the support legs and assumed to resist tension forces only (no compression).

Eight 5 in. $\times 1 / 2$ in. steel bars welded to the support legs as shown in Fig. 35 are adequate to brace the structure for
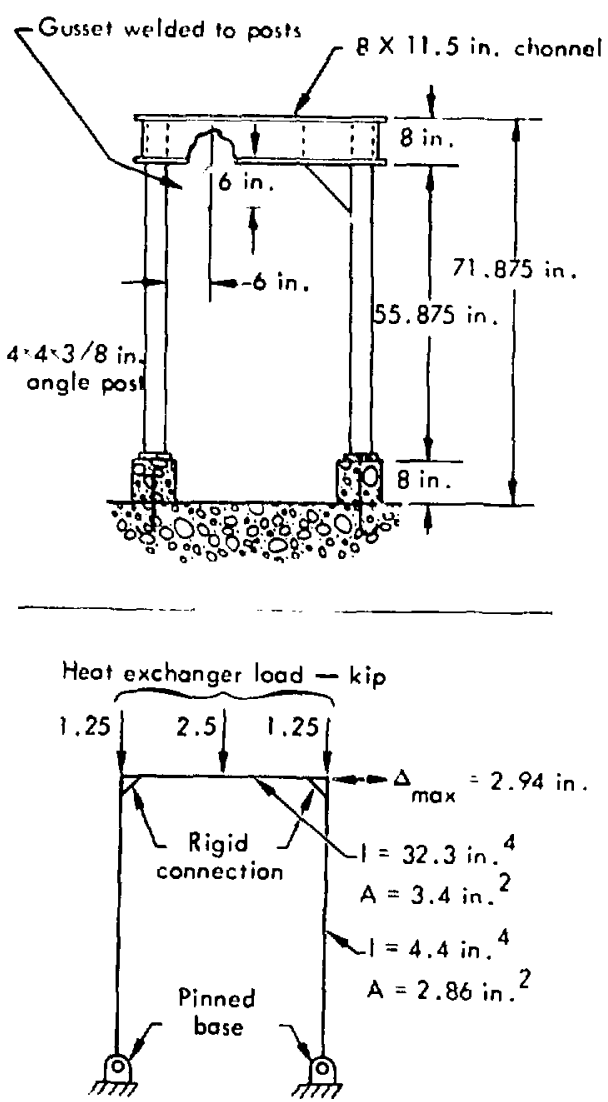

Fig. 34. LPTR heat exchanger support structure and plane frame model used to analyze structure's response to the $\mathrm{SSE}$.

the earthquake loading. Calculated values for stifiness, period, spectral acceleration and maximum lateral displacement are $91.74 \mathrm{kip} / \mathrm{in} ., 0.07 \mathrm{sec}, 463 \mathrm{in.} / \mathrm{sec}^{2}$, and 0.065 in. respertively. For this modification all member and bolt stresses are below allowable design values for A-7 structural steel. 


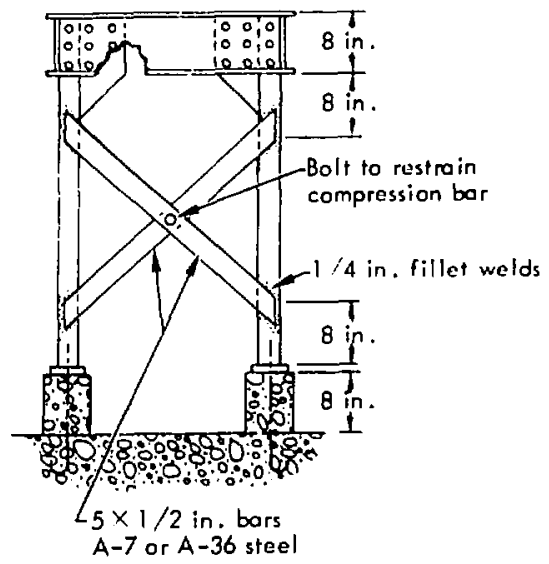

Fig. 35. LPTR heat exchanger support structure crossbracing scheme to improve resistance to lateral earthquake loads.

\section{Conclusions}

Based on the results of the analyses several conclusions have been reached about the seismic behavior of the LPTR facility if subjected to the earthquake loading defined by the SSE.

Maximum reactor shield displacements during an earthquake are within acceplable values. The concrete alone has adequate strength to carry the shear and compressive stresses induced by the SSE; some $y$ ielding of the vertical reinforcing steel is expected. There are adequate mechanisms to transfer the seismic shear to the foundation. No problems are anticipated for the reactor top structure.
The exigting crane and heat exchanger support structures are presently inadequate to resist the SSE. Severe damage or collapse of the heat exchanger support and the overhead bridge crane frame is expected if fully loaded at the time of earthquake occurrence. These deficiencies can easily be corrected by adding bracing and cover plates to the effected members.

Earthquake loading will stress the containment building to approximately $10 \%$ of the 2 psi design internal pressure loading. The building has been proof tested at this internal pressure loading. No problems are expected in the containment structure.

\section{Acknowledgments}

The althors wish to express their appreciation to Richard T. Peterson, Reactor Mechanical Engineer, for his continued assistance and cooperation throughout the study. 


\section{References}

i. Standard Format and Content of Sarety Analysis Rqports for Nuclear Puwer Plams, United States Atomic Energy Commission, Washington (1972).

2. Investigation of Faulting at the Lawrence Livermore Laboratory, I.awrence Livermore Laboratory, Rept, LCR1.-1356R (1972).

3. Plutonium Laboratory, I.awrence Livermore Laboratory, Geologic, Seismologic, and Foundation Investigations, John $\lambda$. Hlume Associates, (1971).

4. J. B. Radcliffe, Jr., k. E. Hith, and G. L. Cummings, The Livermare Pool Type Reactor (LPTH), Lawrence Livermore Laboratory, Rept. UCRL.-4919, Rev, 11 \{1967).

5. D. 1. Bernreuter and F. J. Tokarz, Design Basis Earthquakes for the Lawrence Livermore laboratory Site, l.awrence Livermore Laboratory. Rept. UCRI.$51193(1972)$.

6. J. L. Olsen, Lawrence Livermore Laboratory, Internal Document (1973). Readers outside the l.aboratory who desire further information on L1.1. internal documents should address their inquiries to the Technical Information Department, Lawrence Livermore I aboratory, Livermore, California 94550.

7. R. J. Dietrich, Shannon and Wilson, Inc., Burlingame, California, private communication (November 24, 1971 ).

B. H. B. Seed and I, M. Idriss, A Simplified Procedure for Evaluating Soil Liquefaction Potential, University of California, Earthquake Engineering Research Center, Berkeley, Rept. 70-9, (1970).

9. Seismic Design for Nuclear Power Plants, R. J. Hansen, Ed. (MI'T Press, Cambridge, Mass. 1970) p. 261.

10. L. Jacobsen, J. Appl. Mech. 5, 1 (1938).

11. L. Jacobsen, Trans, ASCE 104, 402 (1939).

12. S. Ghosh and E. Wilson, Dynamic. Stress Analysis of Axisymmetric Structures Under Arbitrary Loading, University of California, Earthquake Engineering Research Center, Berkeley, Rept. 69-10 (1969).

13. L. W. Christensen, Lawrence Livermore Laboratory, Internal Document ENW72-13 (1972).

14. J. M. Raphael, J. Structural Div., Proc, ASCE, 84, ST 1, (1958).

15. H. S, Davis, F. L. Browne, and H. C. Witters, J, Am. Concrete Lnst. 27. ?, \{1956\}.

16. Building Code Requirements for Reinforced Concrete, American Concrete Institute, Pub. 318-63 (1963).

17. E. L. Wilson and H. H. Dovey, Static and Earthquake Analysis of ThreeDimensional Frame and Shear Wall Building, University of California, Earthquake Engineering Research Center, Berkeley, Rept. 72-1 (1972). 
13. M. Stephensen, Lawrence Livermore Laboratory. Internal Documen ENN 72-168 (1972).

19. S. M. Waterman, Civil Eng. 21, (4), 46 (1951).

20. W. P. Doherty and E. L. Wilson, Analysis of Two-Dimensional Frame Structures, (hniversily of California, Berkeley, Computer Programming Serie日 Notes, (1967).

\section{Bibliography}

Earthquake Engineering, R. 1.. Wiegel, Ed., (Prentice-Hall, Inc., Englewood Cliffs, N. J., 1970).

Manual of Steel Construction, (American Institute of Steel Construction, New York, 1965) 6th ed.

J. A. Blume, R. L. Sharp, and G. Kost, Earthquake Engineering for Nuclear Reactor Facilities, J. A. Blume Associates, Rept. JAB-101, 1971.

Nuclear Reactors and Earthquakes, U.S. Atomic Energy Commission, Washington, Rept. TID-7024 (1963). 